\title{
The effect of cash transfers and household vulnerability on food security in Zimbabwe
}

\author{
Garima Bhalla $^{\mathrm{a}, *}$, Sudhanshu Handa ${ }^{\mathrm{b}}$, Gustavo Angeles ${ }^{\mathrm{c}}$, David Seidenfeld ${ }^{\mathrm{d}}$ \\ a Oxford Policy Management Ltd., Level 3, 52 Cornmarket Street, Oxford OX1 3HJ, United Kingdom \\ b Department of Public Policy, Abernethy Hall, CB\# 3435, University of North Carolina at Chapel Hill, Chapel Hill, NC 27599-3435, USA \\ ${ }^{\mathrm{c}}$ Department of Maternal \& Child Health, UNC Gillings School of Global Public Health, University of North Carolina at Chapel Hill, Chapel Hill, NC 27599-7445, USA \\ d American Institutes for Research, 1000 Thomas Jefferson St NW \#200, Washington, DC 20007, USA
}

\section{A R T I C L E I N F O}

\section{Keywords:}

Vulnerability

Food security

Food poor

Zimbabwe

Cash transfers

Social protection

\begin{abstract}
A B S T R A C T
We study the impact of the Zimbabwe Harmonized Social Cash Transfer (HSCT) on household food security after 12 months of implementation. We investigate determinants of food security as measured by a well-known food security scale - the Household Food Insecurity Access Scale (HFIAS) - and as measured by value of household food consumption composed of own-production, market purchases and gifts received. We find that several dimensions of household vulnerability correlate more strongly with the food security measure than with food consumption. Labor constraints, which is a key vulnerability criterion used by the HSCT to target households, is an important predictor of the food security score but not food consumption, and its effect on food security is even larger during the lean season. Impact analysis shows that the program has had statistically significant impacts on Food Security and Diet Diversity scores but null to low impacts on food consumption. However aggregate food consumption hides dynamic activity taking place within the household where the cash is used to obtain more food from the market and rely less on food received as gifts. The cash in turn gives beneficiaries greater choice in their food basket, which improves diet diversity.
\end{abstract}

\section{Introduction}

The United Nations, as part of its post-2015 Sustainable Development Agenda, has declared ending hunger and achieving food security as the second of its 17-goal agenda, to be achieved by 2030 . At present, about 800 million people are still undernourished globally, and the prevalence rate in sub-Saharan Africa is 23 per cent. In Zimbabwe, the proportion of undernourished in the total population is even higher at 33 per cent (FAO, IFAD and WFP, 2015). In 2015-16 food security worsened due to a poor 2015 harvest season and El Niño-induced below normal rains in early 2016. The Government declared a state of national disaster in February 2016 and appealed for USD 1.5 billion aid for food and other emergency needs (FEWS NET, 2016). Addressing the challenge of growing food insecurity requires implementation and scale up of effective social protection programs.

Cash transfers are a policy instrument that can help build household resiliency in obtaining access to food. In their Resilience Index Measurement and Analysis (RIMA) model, Alinovi et al., (2009) include income and food access as one of the six different dimensions that determines resiliency. Alleviating poverty and increasing food consumption are primary objectives of cash transfer programs. In this paper, we use longitudinal data collected for the impact evaluation of Zimbabwe's Harmonized Social Cash Transfer Program (HSCT), an unconditional cash transfer targeted to ultra-poor, labor-constrained households. The Program was introduced in 2011 and initially reached 55,000 households, though with the recent fiscal crisis in the country these numbers may soon go down.

This paper makes contributions to two distinct but inter-related literatures. First, we provide evidence on the relative merits of using an aggregate consumption expenditure measure versus a food security scale to assess household vulnerability and food insecurity. Second, we contribute to a small but growing literature on the effects of statesponsored unconditional cash transfers in Africa on household behavior and food security. Existing evidence on cash transfers is dominated by studies from Latin America on conditional cash transfers, and many of those are from one single program (Progresa/Oportunidades). The generalizability of that evidence to different contexts and without conditions is not straightforward.

\section{Literature review}

Food security is defined as the situation "when all people, at all

\footnotetext{
* Corresponding author.

E-mail address: garims@gmail.com (G. Bhalla).
} 
times, have physical, social and economic access to sufficient, safe and nutritious food to meet their dietary needs and food preferences for an active and healthy life" (FAO, 2009). A common framework utilized by scholars to highlight the different dimensions of food security is a fourtier categorization - availability of food; access to food, which refers to the ability of households to obtain food from the market or own production or gifts; utilization of food; and stability, which is the ability of households to withstand risks and shocks that erode any of the other three dimensions (Webb et al., 2006). During the 1980s, there was a shift of emphasis from food-availability indicators to food-access indicators such as household food consumption expenditure and household food insecurity score. More recently, a further shift in focus has been in moving from objective to experiential measures in recognition of the importance of the experiential aspect of the process that leads to the condition of being hungry. Some households can be food insecure, and yet not immediately experience hunger. The rationale for utilizing experiential-based indicators is that it "puts people's experiences and behavioral responses at the core of the definition of what food security means" (Ballard et al., 2013), rather than focusing on determinants of food security or its outcomes (nutrition). This research led to the development of the Household Food Insecurity Access Scale (HFIAS), by the Food and Nutritional Technical Assistance (FANTA) project of USAID. It is a 9-item scale, with a reference period of the past four weeks where households are asked to rate their experience on a scale from 'Rarely' to 'Often', generating a total score from 0 to 27. It thus "provides a continuous measure of the degree of food insecurity of the household" (Coates et al., 2007). A higher score indicates the household suffers from more food insecurity and is relatively worse off. It captures the experiential aspect of food insecurity by including anxiety about future availability of food; consumption of food items that are not preferred; and limiting diet diversity as part of its construct. These three domains were identified based on the ethnographic work done by Radimer et al. (1990) in the United States. Coates et al. (2006) confirmed these domains to be common across diverse cultural settings.

The HFIAS then, goes beyond a food expenditure measure by capturing not just present food consumption status but also the uncertainty and vulnerability associated with maintaining or improving that status $^{1}$. Vulnerability has been defined in different ways but the basic idea is that it captures the risk or "likelihood that at a given time in the future, an individual will have a level of welfare below some norm or benchmark" (Hoddinott and Quisumbing, 2003). It is a forward-looking concept as opposed to a snapshot in time presented by food consumption expenditure. This distinction has been well documented in the literature on poverty (Dercon, 2001; Chaudhuri et al., 2002; Hoddinott and Quisumbing, 2003). In the food insecurity literature, the direction this research has taken has been generally that of validation studies. Jones et al. (2013) provide a review of four key validation studies of HFIAS in Iran (urban Tehran), Tanzania (poor rural households), Burkina Faso (urban households), and Ethiopia (community health volunteers). They find evidence of the construct validity of the HFIAS and high internal consistency. They also find that the HFIAS score is negatively associated with other proximate determinants for food security such as household wealth/assets, maternal education, husband's education, household per capita income and expenditure, and diet diversity. In Zimbabwe, Nyikahadzoi et al. (2013) found the HFIAS score to be higher in elderly headed households and within these households, food insecurity is negatively associated with social capital, remittances, and off-farm income. In another study among smallholder farmers in the Mudzi district of Zimbabwe, Mango et al. (2014) found that the HFIAS score is predicted by household labor, education of the

\footnotetext{
${ }^{1}$ Aside from construct validity, an additional reason why practitioners might choose to utilize the HFIAS in the field is its relative ease of deployment since it is less time intensive to complete than a complete food consumption module. As a result, it is also less expensive to deploy.
}

household head, household size, remittances, livestock ownership and access to market information. In this paper, we accept the validity of the HFIAS given past research and instead investigate if factors explaining variation in the HFIAS and food expenditure are substantively different.

In this paper we use a longitudinal ward-level matched case-control design to analyze the impact of a cash transfer program implemented in rural Zimbabwe on household food security after 12 months of implementation. The theoretical basis for cash transfer programs is that regularity and predictability of cash payments allow poor households to smooth consumption across the year and build human and physical capital that will allow them to absorb shocks (Arnold et al., 2011; FAO, IFAD and WFP, 2015). Their impacts on food consumption and nutrition have been well documented (Adato and Bassett, 2008; The Kenya CT-OVC Evaluation Team, 2012). According to a comprehensive global review by the Department for International Development of the United Kingdom (Arnold et al., 2011), about half the value of a cash transfer is spent on food. Impacts vary depending on the duration over which the transfer is received, age of the recipient, and size of the transfer. In Malawi, Miller et al. (2011) demonstrate large effect sizes that are statistically significant on food expenditure, consumption, food adequacy, and diet diversity. These large effect sizes are explained in part by the size of the cash transfer, which on average accounted for sixty percent of per capita total household expenditure. However, most of these evaluations do not utilize the standardized HFIAS to measure impact, and evidence from sub-Saharan Africa is still scant.

The relationship between economic status as measured by expenditure or income and calories has been a fundamental line of inquiry in the development literature with some findings supporting the conventional wisdom that as income rises, so does demand for calories while others have found the elasticity between the two to be non significantly different from zero (Behrman and Deolalikar, 1987). In their seminal paper on demand for food and calories, Subramanian and Deaton (1996) find that food expenditure elasticity with respect to total expenditure is driven by elasticity of calories and the elasticity of price of calories in equal measure. So, "A 10 percent increase in food expenditure is associated with a 5 percent increase in calorie consumption and a 5 percent increase in the price paid per calorie" (Subramanian and Deaton, 1996, p.154). In other words, as income increases, people tend to substitute cheaper coarser foods with more expensive, refined calories that taste better. As we shall describe later in this paper, our results of the impact of the cash transfer indicate something similar, in that a greater number of cash beneficiaries are able to diversify their diet and consume foodstuffs that they were earlier not consuming.

One reason they are able to do so is because cash enables them to exercise greater control over their food basket, since with the cash they are able to purchase more foodstuffs from the local market in addition to own-producing in their capacity as farmers, or receiving food gifts. With respect to that latter, theory dictates that the cash transfer may crowd-out food gifts that the beneficiary household receives from either other households that are motivated by altruism or gifts received from charitable organizations. In fact, there exists a substantial body of literature on the empirical analysis of the crowding-out effect of public transfers on private transfers. Angelucci et al. (2012) analyzed the impact of the cash transfer in urban Mexico on loans and in-kind transfers and found that treated households are both, 10 percentage points less likely to receive an in-kind transfer, and observed lower loans for the treated group. Nielsen and Olinto (2007) estimate the impact of conditional cash transfers in Nicaragua and Honduras on three kinds of private transfers: remittances, food transfers, and food/ money donations from NGOs. They find no effect on remittances in either country but an impact on food transfers in Nicaragua. Strobbe and Miller (2011) estimate the crowding effect on three types of private transfers - gifts, remittances, and informal loans. They find that the government cash transfer in Malawi leads to crowding-out for gifts and remittances but not for informal loans. Thus, existing empirical 


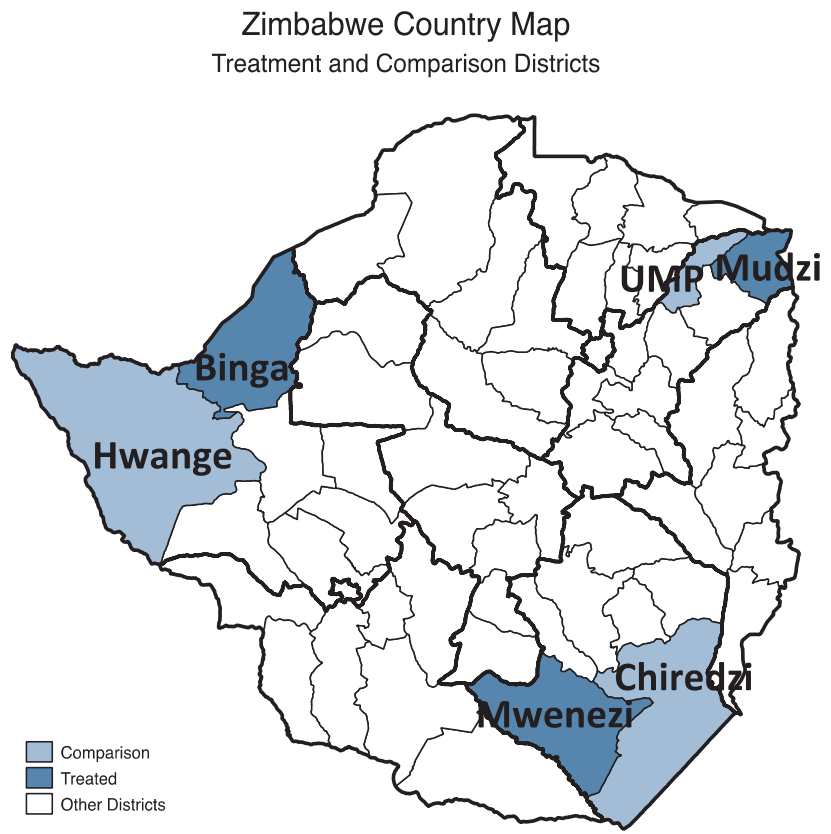

Fig. 1. Map of Zimbabwe. Source: Constructed using Stata 13.1. The darker outlines in the map are province boundaries. Shape files obtained from http://www.gadm.org/.

literature indicates that cash transfer programs impact transfers/gifts received from different sources differently. Crowding-out may occur for certain types of transfers, for example, in-kind transfers of food that are given by a geographically proximate support network. The second part of our paper explores the dynamic between this phenomenon and the impact of the cash transfer on aggregate food expenditure and household food security, having explored the nuanced differences between the two in the first part.

\section{Research setting and Design ${ }^{2}$}

\subsection{The Zimbabwe Harmonized cash transfer program}

Zimbabwe's Harmonized Social Cash Transfer (HSCT) Program was introduced in 2011 and is the country's primary social protection program. In January 2016, the Program covered 52,500 households, and approximately 300,000 households are expected to be eligible for the program at full-scale. It is an unconditional cash transfer program, wherein beneficiary households receive a bimonthly cash transfer that varies with household size: a one-person household receives USD10, two-person receives USD15, three-person receives USD20, and a household made up of four or more persons receives USD25. On average, the transfer size is about 20 percent of total household consumption expenditure.

Eligibility criteria to become a beneficiary are twofold: food-poor and labor constrained status of the household. A household is considered food-poor when it is living below the food poverty line ${ }^{3}$ and is unable to meet the most basic needs of its members. Out of a list of ten indicators ${ }^{4}$ that measure the inability of the household to meet basic needs, a household has to suffer from at least three to be considered

\footnotetext{
${ }^{2}$ This section draws from the following UNICEF Innocenti Working Paper: Bhalla, Garima; Handa, Sudhanshu; Angeles, Gustavo; Seidenfeld, David (2016). The effect of cash transfers and household vulnerability on food insecurity in Zimbabwe, Innocenti Working Papers No. IWP_2016_22, UNICEF Office of Research - Innocenti, Florence.

${ }^{3}$ Food poverty line is the threshold where total household expenditure is below what is required to meet the food energy requirement for each household member, set at $2100 \mathrm{kcal} /$ day/person.

${ }^{4}$ The 10 indicators as given in Form1R, which is used for assessing eligibility. For reasons of confidentiality we do not specify these indicators here.
}

eligible for the Program.

A household is considered labor constrained when $^{5}$ :

1. There is no able bodied household member between 18 and59 years who is fit for productive work, OR

2. The dependency ratio is three or more, i.e., one fit to work household member between $18-59$ years has to take care of three or more dependents. Dependents are those household members who cannot or should not work because they are under 18 years of age or they are elderly (over 59 years of age) or they are unfit for work because they are chronically ill or disabled or still in school, OR

3. The dependency ratio is between two and three and the household has a severely disabled or chronically sick household member who requires intensive care

Eligible households for the Program were identified through a detailed targeting census, in which all households are screened using the targeting survey fielded by Zimbabwe's national statistical agency, ZIMSTAT. Program implementation is being done in a phased manner and it is anticipated that eventually the Program will cover the entire country.

\subsection{Study design}

The phased roll out of the HSCT allows us to use households slotted to enter the program at a later date as a potential comparison group. The program operates at an administrative unit known as the Ward, which is one level below districts. Child Protection Committees (CPCs) at the Ward level ensure that targeting of households is conducted thoroughly and communicate program rules to beneficiary households. We utilize the Ward as the primary sampling unit for the sample design.

Phase 1 of the HSCT expansion occurred in 2011-12 and covered ten districts. Wards for the treatment group of the evaluation were selected from Phase 2 areas, which entered the program in 2013. Wards for the comparison group were selected from areas that were slotted for Phase Four expansion and that were geographically close to Phase 2

\footnotetext{
${ }^{5}$ Throughout the paper, we use this definition to operationalize the attribute of being labor constrained
} 


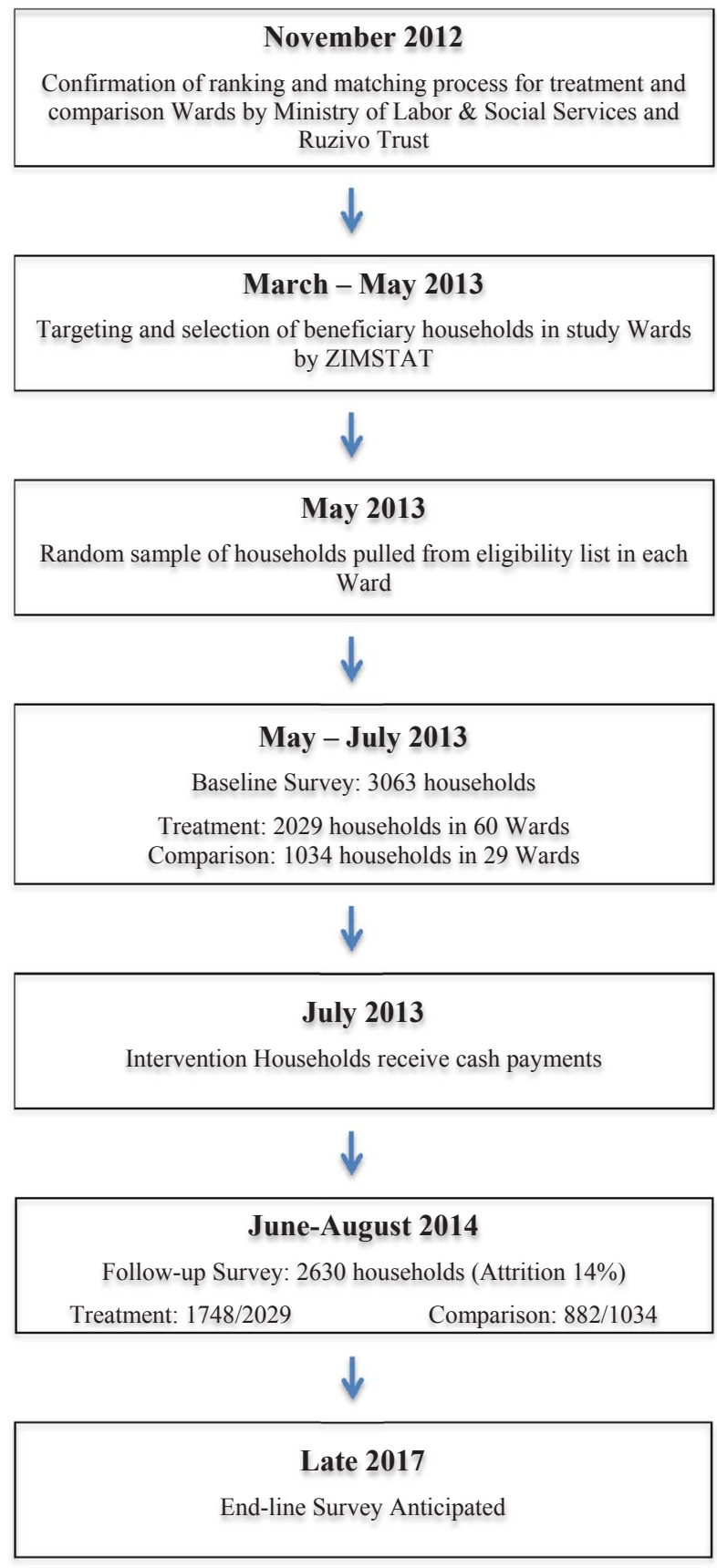

Fig. 2. Study flow chart.

areas. Treatment Wards were stratified across the three treatment districts (Mudzi, Mwenezi and Binga), and comparison Wards were likewise stratified to areas adjacent to the three treatment districts. Fig. 1 provides a map showing the geographic location within Zimbabwe of the study sites. Our national research partner Ruzivo Trust led a detailed analysis of all Wards in these areas and assigned a point score from 1 (low) to 3 (high) to each Ward on five characteristics: forest cover, nearness to main roads, resistance to shocks, nearness to business centers, and water sources. ${ }^{6}$

Power calculations based on the expected number of households per Ward indicated that a total of 60 Treatment and 30 Comparison Wards

\footnotetext{
${ }^{6}$ Details of the Ward level analysis are available upon request. One matched comparison Ward was dropped from the Study because it did not have any eligible households. Our study therefore has a total of 89 Wards
}

were necessary for the study. ${ }^{7}$ Wards in treatment areas were ranked from highest point score (most vulnerable) to lowest and paired within each stratum. Then, for each treatment Ward pair with a given score, a comparison Ward with the same score in the same stratum was selected to serve as the 'matched' comparison Ward. If no comparison Ward existed with the exact same score, the Ward with the closest point score was selected. If more than one comparison Ward existed with the same score, then one Ward of the two was picked randomly.

The Department of Social Services conducted program targeting in the selected study Wards, as per standard program operation guidelines. Therefore, all households in comparison Wards in the study sample are actual eligible households who will receive benefits once the program reaches their area. Since, eligibility criteria are the same across the country and there is universal program take-up, these households thus serve as a close approximation of the perfect counterfactual for treatment households. The distinction between this design and a randomized control trial is that Wards were not randomly assigned to treatment or control status. In a large-scale national program, randomization of roll out is often not feasible since program roll out is determined by both technical (e.g. poverty) and political considerations. In the HSCT, program operations called for complete scale-up in a district once that district entered the program, thus there was no possibility of drawing control Wards from the same district. However if the eligibility criteria are applied uniformly, targeting is supply-driven, and take-up is universal, then the only threat to internal validity is the geographical differences across Phase 2 and Phase 4 areas. Our stratified matched design was chosen to minimize geographical differences.

Out of the identified eligible households, the evaluation team randomly selected 34-60 households in each ward, using the random number generator tool in excel. This generated a sample of 3063 households across 90 wards $^{8}$. Data were collected through a detailed household survey, conducted at baseline and 12-month follow-up. At follow up, the household attrition rate was 14 per cent. As part of the impact evaluation, detailed attrition analysis was conducted, and while differential attrition was ruled out, it was concluded that overall attrition (households remaining in the study were no longer representative of households in the original sample) might be a problem (American Institutes for Research, 2014). To correct for this problem, inverse probability weighting was used to adjust sampling weights. We use these generated analytical weights for our panel data impact analysis. A study flow chart is provided in Fig. 2.

\section{Household characteristics and food security}

4.1. Socioeconomic characteristics associated with food security and food consumption

We utilize Ordinary Least Squares (OLS) to understand if the HFIAS is capturing information about a household's vulnerability that conventional food access measures, such as food consumption expenditure, are not able to detect. Theoretically, the HFIAS should inform us not just about a household's food consumption status, but also about the anxiety it experienced to sustain that level of food consumption. For ease of comparison with other indicators we positively code the HFIAS so that higher scores indicate better food security, and refer to it as Food Security.

Table 1 presents the results of the OLS analysis where our two measures of food security, the Food Security Score and Log of per capita Food Consumption Expenditure, are regressed on proximate determinants of food security using baseline data only. Since our two dependent variables

\footnotetext{
${ }^{7}$ Sample size calculations were based on the power to detect a meaningful change in the height-for-age z-score of children under age 60 months, the indicator for which the largest effective sample size was required (Handa et al., 2013).

${ }^{8}$ For our food consumption analyses, we drop observations that are below 0.1 percentile and beyond 99.9 percentile of the distribution, giving us a total baseline sample of 3051 and panel sample of 2623 households
} 
Table 1

Estimates of socioeconomic characteristics of households associated with food security score and per capita food consumption expenditure.

\begin{tabular}{|c|c|c|c|c|}
\hline \multirow[b]{2}{*}{ Household Demographics } & \multicolumn{2}{|c|}{$\begin{array}{l}\text { (1) } \\
\text { Food security score }\end{array}$} & \multicolumn{2}{|c|}{$\begin{array}{l}\text { (2) } \\
\text { Log per capita food consumption } \$\end{array}$} \\
\hline & Estimate & Std. Error & Estimate & Std. Error \\
\hline \multicolumn{5}{|l|}{ Household demographics } \\
\hline Household size (log) & 0.280 & 0.968 & $-1.493^{\text {k*kik }}$ & 0.104 \\
\hline \# Children under 5 & -0.293 & 0.246 & $0.087^{\text {thatk }}$ & 0.027 \\
\hline \# Children 6-17 & $-0.423^{k * k}$ & 0.179 & $0.082^{*+3 \times k}$ & 0.022 \\
\hline \# Adults 18-59 & -0.401 & 0.242 & $0.093^{* * * k}$ & 0.017 \\
\hline \# Elderly $(>60)$ & -0.132 & 0.271 & $0.098^{* * \times \times x}$ & 0.029 \\
\hline \multicolumn{5}{|l|}{ Main respondent characteristics } \\
\hline Female $($ Yes $=1)$ & -0.423 & 0.292 & $-0.070^{* *}$ & 0.031 \\
\hline Age (Years) & $-0.028^{* * * *}$ & 0.010 & $-0.002^{*}$ & 0.001 \\
\hline Widowed $($ Yes $=1)$ & -0.322 & 0.303 & 0.025 & 0.037 \\
\hline Divorced/separated $($ Yes $=1)$ & 0.052 & 0.456 & 0.021 & 0.045 \\
\hline Main resp. has schooling (Yes $=1$ ) & $0.592 *$ & 0.305 & $0.075^{* * *}$ & 0.032 \\
\hline \multicolumn{5}{|l|}{ Other socioeconomic Characteristics } \\
\hline Distance to food market $(\mathrm{km})$ & $-0.077^{* * *}$ & 0.025 & 0.001 & 0.002 \\
\hline Distance to input market $(\mathrm{km})$ & $0.022^{k \ldots k}$ & 0.008 & 0.001 & 0.001 \\
\hline Distance to water source $(\mathrm{km})$ & -0.015 & 0.118 & -0.008 & 0.009 \\
\hline Productive assets score $^{\mathrm{a}}$ & $0.508^{* * *}$ & 0.089 & $0.074^{\text {stonk }}$ & 0.008 \\
\hline Household amenities score ${ }^{\mathrm{b}}$ & $0.527^{* \ldots *}$ & 0.106 & $0.051^{n+\infty * k}$ & 0.010 \\
\hline \# Of livestock type & 0.097 & 0.103 & $0.037^{* \ldots k k}$ & 0.008 \\
\hline $\begin{array}{l}\text { Any income from wage labor? } \\
\quad(\text { Yes }=1)\end{array}$ & $1.530^{\text {*k*k }}$ & 0.462 & 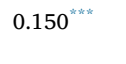 & 0.040 \\
\hline $\begin{array}{l}\text { Any income from maricho labor? } \\
\quad(\text { Yes }=1)\end{array}$ & $-0.786^{k *}$ & 0.305 & 0.036 & 0.024 \\
\hline $\begin{array}{l}\text { Planted crops last rainy season } \\
\quad(\text { Yes }=1)\end{array}$ & $1.713^{k * * *}$ & 0.513 & -0.010 & 0.043 \\
\hline Labor constrained $($ Yes $=1)$ & $-0.897^{k * k}$ & 0.386 & -0.010 & 0.043 \\
\hline Aid received (in USD) & -0.001 & 0.002 & 0.000 & 0.000 \\
\hline $\begin{array}{l}\text { Monthly remittances low }(<\$ 25 / \\
\text { month) }\end{array}$ & $-1.324^{k * k}$ & 0.518 & $-0.184^{* * \ldots * k}$ & 0.040 \\
\hline Has loan outstanding $($ Yes $=1)$ & -0.580 & 0.376 & $0.116^{* * *}$ & 0.045 \\
\hline \multicolumn{5}{|l|}{ Other covariates } \\
\hline Suffered from a shock? (Yes =1) & $-1.961^{\text {k*** }}$ & 0.403 & 0.004 & 0.036 \\
\hline Mashona indicator & $-1.256^{* k *}$ & 0.353 & $0.251^{m+2 \times x+x}$ & 0.043 \\
\hline Masvingo indicator & $-1.039^{k * k}$ & 0.448 & $0.254^{2 * x+2}$ & 0.036 \\
\hline Constant & $18.986^{* * * k}$ & 1.444 & $4.759^{* \ldots * k}$ & 0.133 \\
\hline Observations & 3034 & & 3034 & \\
\hline Adjusted R-squared & 0.130 & & 0.466 & \\
\hline
\end{tabular}

Notes: Standard errors clustered at the ward level. Standardized baseline weights utilized.

${ }^{a}$ Productive assets score obtained through Principal Components Analysis of 30 different variables that indicate ownership of assets such as tractor, plough, and other agricultural tools

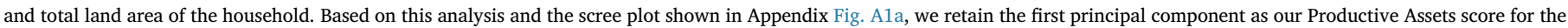
household, which explains 21.5 per cent of the variability in the data. The subsequent components each explain less than six per cent of the variation.

${ }^{\mathrm{b}}$ Household Amenities score also obtained through Principal Components Analysis of variables that indicate ownership of the following amenities: a toilet, a cooking room, ventilation

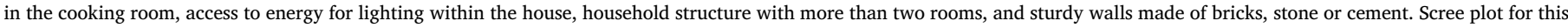
analysis is shown in Appendix Fig. A1b. We retain the first component as the Amenities score for the household. It explains 31.3 per cent of the variation among the variables.

$* \mathrm{p}<.1$.

$* * \mathrm{p}<.05$.

$* * * \mathrm{p}<.01$

are measured on different scales, we cannot directly compare coefficient estimates. However, we can compare which factors are significant in explaining variation in each measure. As expected, we find that the larger the household size, the lower the value of its per capita food consumption. However, the relationship between household size and the Food Security score is not significant. Female-headed households have on average about seven per cent lower value of per capita food consumption, and age of main respondent is significant across both measures, although the magnitude of the estimate is small. If the main respondent has attended school then the Food Security score is higher by 0.6 points and per capita food consumption value increases by about eight percent. ${ }^{9}$

\footnotetext{
${ }^{9}$ The main respondent is the person that is interviewed when we visit the household to conduct our survey. Typically, the main respondent is the head of the household. However, at times the head is away when the survey team is visiting and in such cases, we interview a member of the household who is available to answer questions.
}

The main results of Table 1 are in the socioeconomic characteristics section. As expected, ownership of productive assets and presence of household amenities such as sturdy walls and toilet facilities positively impact food consumption and the Food Security score. Wage income has large significant impacts on both consumption and the Food Security score. Conversely, low level of monthly remittances, signifying absence of a strong support system, has a large negative impact on both food consumption and food security. However, some variables such as labor-constrained status of the household, which directly indicate the vulnerability of the household due to the uncertainty they introduce in the household's source for food, are significant in only explaining Food Security score, but not food consumption. Other variables that impact only the Food Security score are indicators for whether the household earns any income from casual labor (referred to in Zimbabwe as maricho), has planted any crops in the last rainy season, or has suffered from any shock in the last 12 months. Maricho or casual wage labor is the fall back option for subsistence households throughout rural Africa, 


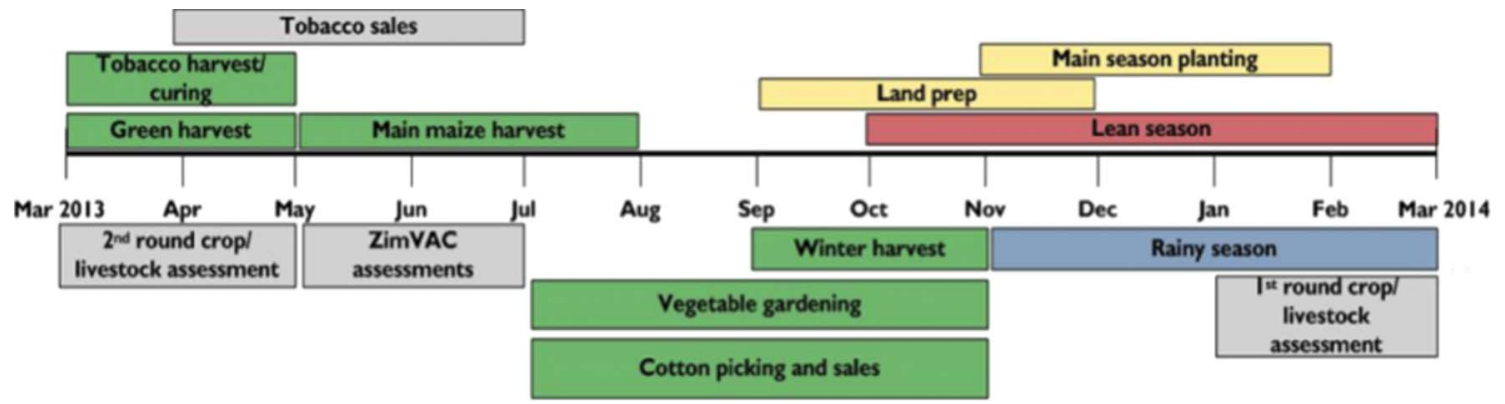

Fig. 3. Zimbabwe seasonal calendar. Source: Famine Early Warning Systems Network.

and is undertaken by landless or extremely poor households, or when the household suffers a shock or when grain stocks have run out and cash is needed. These results suggest that households smooth their consumption across time and their vulnerability in maintaining that consumption level is not immediately reflected in aggregate value of food consumption, but it is captured by the Food Security score.

\subsection{Initial harvest period vs. Peak harvest period}

We extend our vulnerability analysis by taking into account the fact that the baseline survey was implemented between April and June, so that some households were interviewed just prior to harvest and others during or just after. In an agrarian rural setting such as the one in which the HSCT was implemented, the time of the harvest can make a big difference to the food status of household members. Most rural households rely heavily on own-production of cereals, but also rely on the market, as own-production is not sufficient to meet their food requirements (FEWS NET, 2014).

Fig. 3 provides a graphic representation of Zimbabwe's typical seasonal calendar. Zimbabwe has a unimodal rainy season lasting from November to March. This is also the main planting season of the year. Tobacco is the main cash crop of Zimbabwe and its harvest begins in March. The main maize harvest, which is the staple crop of the country, begins in May. The peak vegetable gardening and cotton-picking season then begins in July. Food insecurity starts increasing around September/October as grain stores from the last harvest are depleted by then (FEWS NET, 2013).

Fig. 4 depicts how the Food Security score progresses across AprilJune, the survey window for 2013, and also the period when households are beginning to move out of the lean season to initial and then peak harvest period when they are typically flush with grains from ownproduction. Note that the food security score is based on a four-week reference period. Households interviewed in April/May were requested to think back to March/April, when they would have not yet entered the maize harvest period. As seen in Fig. 4, there is a discontinuity during the week of May 14-21, after which households' food security begins to progressively improve. This presents an opportunity to divide the sample according to initial vs. peak harvest period to understand if the standard set of socioeconomic and demographic factors influences food security differently in a relatively worse-off vs. better-off period. We do not include Mashonaland East in this part of our analysis since no households in that province were approached during peak harvest period.

Results of our seasonality analysis are presented in Table 2, where we estimate a fully interacted model that allows all effects to differ between initial harvest and peak harvest period by interacting each covariate with an indicator variable for 'Pre/Initial Harvest'. Analytically, this model is equivalent to estimating separate models for the two groups, but an interacted model has the advantage of testing statistical differences between the two. We find that although the Chow tests inform us that the two groups/periods are jointly different, only a few

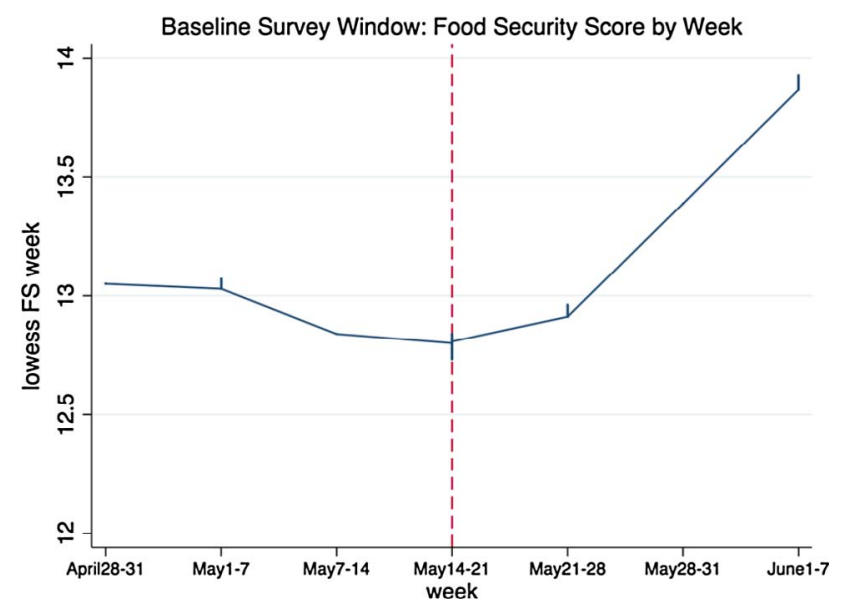

Fig. 4. Food security score by week.

of the individual interaction terms emerged as significant. In Table 2, we control for all variables as shown in Table 1, but here we show only those variables for which a significant interaction term emerges. The full results of the interacted model are presented in Table A1 of the Appendix.

Maricho labor income increases food consumption during peak harvest but during pre-harvest, it hurts the food security score of households. This suggests that households that engage in maricho labor in the pre-harvest period are poorer and are forced to rely on casual labor. Importantly, we find that if the household is labor constrained or receives low monthly remittances, its food security is weakened in this period. Being labor constrained stands out as an especially vulnerability-inducing attribute. It is important to note that several social protection programs throughout Africa - Ethiopia, Liberia, Malawi, Rwanda, Uganda and Zambia - utilize labor-constrained status as a targeting criterion for identifying program beneficiaries. ${ }^{10}$

\section{Impact of the HSCT program on household food security}

\subsection{Summary statistics}

Table 3 reports mean characteristics at baseline for both treatment and comparison groups. We retain only the panel sample of households for this part of our analysis. There are 1740 households in the treatment group and 879 in the comparison group. To test for baseline balance between the two groups, we use OLS regressions with clustered

\footnotetext{
${ }^{10}$ Some program names include the Malawi Social Cash Transfer Program, the Kenya Cash Transfer for Orphans and Vulnerable Children, Ghana's Livelihood Empowerment Against Poverty, Ethiopia's Productive Safety Net Program-Direct Support, and the Mozambique Food Subsidy Program (Garcia and Moore, 2012).
} 


\begin{tabular}{|c|c|c|c|c|}
\hline & \multicolumn{2}{|c|}{$\begin{array}{l}\text { (1) } \\
\text { Food Security Score }\end{array}$} & \multicolumn{2}{|c|}{$\begin{array}{l}\text { (2) } \\
\text { Log P.C. Food Consumption }\end{array}$} \\
\hline & Estimate & Interacted Estimate & Estimate & Interacted Estimate \\
\hline Pre/Initial harvest dummy & $\begin{array}{l}5.799^{*} \\
(3.092)\end{array}$ & & $\begin{array}{l}-0.104 \\
(0.267)\end{array}$ & \\
\hline \# Adults 18-59 & $\begin{array}{l}0.103 \\
(0.340)\end{array}$ & $\begin{array}{l}-0.903^{* * *} \\
(0.447)\end{array}$ & $\begin{array}{l}0.098^{* k+k x} \\
(0.032)\end{array}$ & $\begin{array}{l}0.027 \\
(0.041)\end{array}$ \\
\hline Distance to food market & $\begin{array}{l}-0.100^{* *} \\
(0.042)\end{array}$ & $\begin{array}{l}0.099^{*} \\
(0.054)\end{array}$ & $\begin{array}{l}0.005^{*} \\
(0.003)\end{array}$ & $\begin{array}{l}-0.011^{*} \\
(0.006)\end{array}$ \\
\hline Distance to input market & $\begin{array}{l}0.038^{\text {knkx }} \\
(0.013)\end{array}$ & $\begin{array}{l}-0.035^{*} \\
(0.020)\end{array}$ & $\begin{array}{l}0.000 \\
(0.001)\end{array}$ & $\begin{array}{l}-0.000 \\
(0.001)\end{array}$ \\
\hline Any income from maricho labor? $($ Yes $=1)$ & $\begin{array}{l}-0.281 \\
(0.527)\end{array}$ & $\begin{array}{l}-1.410^{\text {ktk }} \\
(0.632)\end{array}$ & $\begin{array}{l}0.071 \\
(0.042)\end{array}$ & $\begin{array}{l}-0.046 \\
(0.062)\end{array}$ \\
\hline Labor constrained $($ Yes $=1)$ & $\begin{array}{l}0.784 \\
(0.700)\end{array}$ & $\begin{array}{l}-3.422^{1+k \times k} \\
(1.060)\end{array}$ & $\begin{array}{l}0.010 \\
(0.064)\end{array}$ & $\begin{array}{l}0.066 \\
(0.075)\end{array}$ \\
\hline Monthly remittances low ( $<\$ 25 /$ month) & $\begin{array}{l}-0.317 \\
(0.774)\end{array}$ & $\begin{array}{l}-2.709^{\text {ikt }} \\
(1.071)\end{array}$ & $\begin{array}{l}-0.141^{* * *} \\
(0.070)\end{array}$ & $\begin{array}{l}-0.099 \\
(0.081)\end{array}$ \\
\hline Masvingo & $\begin{array}{l}-0.448 \\
(0.628)\end{array}$ & $\begin{array}{l}-1.240 \\
(0.856)\end{array}$ & $\begin{array}{l}0.209^{2 k \ldots \hbar n} \\
(0.046)\end{array}$ & $\begin{array}{l}0.149^{2 * x} \\
(0.073)\end{array}$ \\
\hline Constant & $\begin{array}{l}15.191^{* * *} \\
(2.559)\end{array}$ & & $\begin{array}{l}4.795^{x} \\
(0.234)\end{array}$ & \\
\hline Observations & 2121 & & 2121 & \\
\hline
\end{tabular}

Notes: Standard errors in parentheses, clustered at the ward level. Standardized baseline weights utilized.

The model controls for all variables as shown in Table 3. Only significant interaction terms are shown in this table.

$* \mathrm{p}<.1$.

$* * \mathrm{p}<.05$.

$* * * \mathrm{p}<.01$

standard errors at the ward level (to account for clustering of households within wards). Mean differences in a set of 30 key household characteristics were tested, and none of these were found to be statistically different at the five per cent level at baseline.

Average household size in the sample is about five, with a per capita monthly expenditure of \$32-33. More than two-thirds of the main respondents are women, their average age is 56 years, and more than half have had at least some level of schooling. Around 25-28 percent of these households take care of one or more disabled members. In addition, around 37 percent have at least one member who is chronically ill and almost two-thirds have one or more elderly members. These characteristics contribute to a high dependency ratio, which is reflected in the large number of households that are categorized as labor constrained (about $83-84$ percent of the sample ${ }^{11}$ ). That our sample should have such a high concentration of labor-constrained households makes sense because as mentioned earlier, one of the program criterions for household eligibility is labor-constrained status of the household. This demographic profile is also reflected in the unique $\mathrm{U}$ shape of the age distribution among HSCT households shown in Fig. A2 of the Appendix. There are a large proportion of young people (almost 60 per cent of individuals in our sample are below 18 years of age, and most are adolescents), a few working-age adults, and then the distribution again expands to indicate a higher concentration of people beyond age 60 . This profile reflects the 'missing generation' problem characterizing much of sub-Saharan Africa, wherein older caregivers are providing for adolescents, because prime-age, able-bodied workers are 'missing', due to high mortality rates induced by high HIV/AIDS prevalence rates. The addition of the labor-constrained criterion in addition to food poverty is important because it led to the selection of socially vulnerable households.

Table 4a provides means of food security measures across our two time periods. A higher Food Security score indicates the household has

\footnotetext{
11 The reason this is not hundred percent is because the questions used to determine labor constraint are not exactly identical in the evaluation survey and the targeting form used by ZIMSTAT, and the two sets of data were collected at different times.
}

higher food security and is relatively better off. Cronbach's alpha for the food security scale in the two time periods is $0.86-0.87$, suggesting that the sub items of the scale have relatively high internal consistency. ${ }^{12,13}$ The average Food Security score increased from 13 at baseline to above 16 at follow-up, a pattern that holds for both treatment and comparison groups. This improvement is because the baseline survey window began in the pre-harvest season (April-June 2013) while the follow-up survey in 2014 was conducted entirely during peak harvest time (June-September 2014) when households are generally flush with food supplies.

Value of average household food consumption per person per month has decreased by a dollar for the treatment group and almost two dollars for the comparison group. Kernel densities of the Food Security score and $\log$ of per capita monthly food consumption are provided in Fig. A3 of the Appendix.

A widely used indicator of diet diversity is the Diet Diversity Score (DDS), which measures the number of different food groups consumed over a given reference period with a score ranging from 0 to 12 , since there are 12 food groups ${ }^{14}$ recommended for inclusion (Swindale and Bilinsky, 2006). Average household diet diversity based on this score increased from about 6 at baseline to 6.76 for the comparison group

\footnotetext{
${ }^{12}$ The nine sub-items of the scale items are: 1) did you worry that your household would not have enough food?, 2) were you or any household member not able to eat the kinds of food you preferred because of a lack of resources?, 3) did you or any household member have to eat a limited variety of foods due to a lack of resources?, 4) did you or any household member have to eat some foods that you really did not want to eat because of a lack of resources to obtain other types of food?, 5) did you or any household member have to eat a smaller meal than you felt you needed because there was not enough food?, 6) did you or any household member have to eat fewer meals in a day because there was not enough food?, 7) was there ever no food to eat of any kind in your household because of lack of resources to get food?, 8) did you or any household member go to sleep at night hungry because there was not enough food?, and 9) did you or any household member go a whole day and night without eating anything because there was not enough food?

${ }^{13}$ Cronbach's alpha is a measure of internal consistency and is used as a measure of scale reliability. It measures how closely related a set of items are as a group. Generally, a coefficient of 0.80 or higher is considered acceptable for conducting research.

14 The 12 food groups are: Cereals; Roots and Tubers; Vegetables; Fruits; Meat/Poultry; Eggs; Fish/seafood; Pulses and Legumes; Milk and Milk products; Oil/Fats; Sugar/honey; and Miscellaneous (species and beverages).
} 
Table 3

Mean baseline characteristics of sample households.

\begin{tabular}{|c|c|c|c|c|c|}
\hline & \multicolumn{2}{|c|}{ Comparison Group } & \multicolumn{2}{|c|}{ Treatment Group } & \multirow[t]{2}{*}{$p$-value of difference } \\
\hline & Mean & Std. Error & Mean & Std. Error & \\
\hline \multicolumn{6}{|l|}{ Household demographics } \\
\hline Household size & 5.18 & 0.193 & 5.02 & 0.142 & 0.504 \\
\hline \# Children under 5 & 0.80 & 0.061 & 0.76 & 0.048 & 0.550 \\
\hline \# Children 6-17 & 2.24 & 0.110 & 2.23 & 0.081 & 0.931 \\
\hline \# Adults 18-59 & 1.28 & 0.087 & 1.20 & 0.052 & 0.407 \\
\hline \# Elderly $(>60)$ & 0.85 & 0.042 & 0.83 & 0.032 & 0.801 \\
\hline$\%$ of households that have disabled members & $28.05 \%$ & 0.017 & $25.34 \%$ & 0.015 & 0.222 \\
\hline$\%$ of households that have chronically ill members & $37.74 \%$ & 0.024 & $36.71 \%$ & 0.015 & 0.712 \\
\hline$\%$ of households that have elderly members & $64.57 \%$ & 0.028 & $64.12 \%$ & 0.022 & 0.894 \\
\hline \multicolumn{6}{|l|}{ Main respondent characteristics } \\
\hline$\%$ Female & $65.53 \%$ & 0.021 & $69.65 \%$ & 0.016 & 0.116 \\
\hline Age (Yrs.) & 56.35 & 1.255 & 56.27 & 0.881 & 0.951 \\
\hline$\%$ Widowed & $36.77 \%$ & 0.020 & $37.15 \%$ & 0.017 & 0.883 \\
\hline \% Divorced/separated & $8.17 \%$ & 0.011 & $9.54 \%$ & 0.011 & 0.389 \\
\hline$\%$ Main resp. has schooling & $60.53 \%$ & 0.025 & $55.83 \%$ & 0.019 & 0.129 \\
\hline \% Main resp. currently attends school & $1.32 \%$ & 0.005 & $1.66 \%$ & 0.003 & 0.586 \\
\hline Highest grade of Main resp & 3.49 & 0.129 & 3.30 & 0.136 & 0.307 \\
\hline \multicolumn{6}{|l|}{ Other socioeconomic characteristics } \\
\hline Monthly per capita total expenditure (in usd) & 33.43 & 1.412 & 32.01 & 1.037 & 0.418 \\
\hline Monthly per capita food expenditure (in usd) & 20.81 & 1.001 & 20.33 & 0.824 & 0.714 \\
\hline HFIAS Score (1-27) & 13.93 & 0.386 & 14.03 & 0.267 & 0.841 \\
\hline Diet diversity score $(1-10)$ & 6.27 & 0.151 & 5.94 & 0.119 & 0.089 \\
\hline Distance to food market $(\mathrm{km})$ & 3.36 & 0.466 & 3.87 & 0.238 & 0.316 \\
\hline Distance to input market (km) & 20.51 & 2.246 & 18.74 & 1.477 & 0.508 \\
\hline Distance to water source $(\mathrm{km})$ & 1.29 & 0.210 & 1.36 & 0.112 & 0.760 \\
\hline \# Of livestock type & 2.29 & 0.085 & 2.21 & 0.082 & 0.477 \\
\hline$\%$ Households that receive wages & $11.09 \%$ & 0.012 & $10.21 \%$ & 0.010 & 0.575 \\
\hline$\%$ Households undertaking casual/maricho labor & $48.87 \%$ & 0.034 & $46.20 \%$ & 0.022 & 0.513 \\
\hline$\%$ Households that planted crops last season & $86.89 \%$ & 0.026 & $90.11 \%$ & 0.009 & 0.247 \\
\hline$\%$ Households categorized as labor constrained & $82.91 \%$ & 0.020 & $83.97 \%$ & 0.012 & 0.647 \\
\hline Aid received (in USD) & 77.67 & 14.210 & 54.35 & 3.445 & 0.111 \\
\hline$\%$ Of households that have an outstanding loan & $8.85 \%$ & 0.008 & $9.37 \%$ & 0.013 & 0.741 \\
\hline$\%$ Of households that have suffered from a shock & $86.87 \%$ & 0.020 & $90.04 \%$ & 0.013 & 0.190 \\
\hline $\mathrm{N}$ & 879 & & 1740 & & \\
\hline
\end{tabular}

Notes: Attrition-adjusted weighted results, p-values obtained by clustering at ward level.

Table 4a

Mean of food security measures.

\begin{tabular}{|c|c|c|c|c|c|}
\hline & \multicolumn{2}{|c|}{ Comparison } & \multicolumn{2}{|c|}{ Treatment } & \multirow{2}{*}{$\begin{array}{l}p \text {-value baseline } \\
\text { difference }\end{array}$} \\
\hline & Baseline & Follow-up & Baseline & Follow-up & \\
\hline Food security score & 13.07 & 16.34 & 12.98 & 16.46 & 0.841 \\
\hline P.C. Food consumption $\$$ per month & 20.81 & 19.09 & 20.33 & 19.33 & 0.714 \\
\hline Diet diversity score & 6.27 & 6.76 & 5.94 & 7.16 & 0.089 \\
\hline $\mathrm{N}$ & 879 & 880 & 1742 & 1743 & \\
\hline
\end{tabular}

Notes: Attrition-adjusted weighted results, p-values is of baseline difference between the two groups and obtained by clustering at ward level.

Table 4b

Correlation matrix of food security measures using baseline data.

\begin{tabular}{lll}
\hline & Food security score & P.C. Food consumption \$ per month \\
\hline Food security score & 1 & \\
P.C. Food consumption \$ per month & 0.1361 & 1 \\
Diet diversity score & 0.2604 & 0.3482 \\
\hline
\end{tabular}

Notes: Attrition-adjusted weighted results. 
Table 5

Difference-in-differences model: impact on food security measures.

\begin{tabular}{|c|c|c|c|}
\hline & (1) & (2) & (3) \\
\hline & Per capita Food Consumption & Household Food Security Score & Household Diet Diversity Score \\
\hline \multicolumn{4}{|l|}{ On the full sample } \\
\hline \multirow[t]{2}{*}{ Impact estimate } & 1.055 & $1.188^{* * *}$ & $0.753^{\text {vektikn }}$ \\
\hline & $(1.271)$ & $(0.559)$ & $(0.204)$ \\
\hline \multirow[t]{2}{*}{ Treatment indicator } & 0.086 & $1.370^{* * * * k}$ & -0.129 \\
\hline & $(1.080)$ & $(0.485)$ & $(0.162)$ \\
\hline \multirow[t]{2}{*}{ Follow-up indicator } & -4.847 & $-5.230^{k+k \times k}$ & 0.055 \\
\hline & $(3.630)$ & $(1.781)$ & $(0.647)$ \\
\hline \multirow[t]{2}{*}{ Week of interview } & 0.287 & $0.814^{* * *}$ & 0.037 \\
\hline & $(0.335)$ & $(0.174)$ & $(0.063)$ \\
\hline Observations & 5244 & 5244 & 5244 \\
\hline Adjusted R-squared & 0.322 & 0.119 & 0.191 \\
\hline \multicolumn{4}{|c|}{ On small households ((Household Size $<=4$ members) } \\
\hline \multirow[t]{2}{*}{ Impact estimate } & 2.146 & 0.856 & $0.767^{* \cdots * k}$ \\
\hline & $(2.705)$ & $(0.710)$ & $(0.269)$ \\
\hline \multirow[t]{2}{*}{ Treatment indicator } & -0.061 & 0.339 & -0.330 \\
\hline & $(1.860)$ & $(0.574)$ & $(0.223)$ \\
\hline \multirow[t]{2}{*}{ Follow-up indicator } & -7.463 & -1.187 & 0.935 \\
\hline & $(7.257)$ & $(2.249)$ & $(0.903)$ \\
\hline \multirow[t]{2}{*}{ Week of interview } & 0.306 & $0.388^{*}$ & -0.043 \\
\hline & $(0.658)$ & $(0.216)$ & $(0.088)$ \\
\hline Observations & 2354 & 2354 & 2354 \\
\hline Adjusted R-squared & 0.221 & 0.089 & 0.214 \\
\hline
\end{tabular}

Notes: Standard errors clustered at the Ward level in parentheses. Estimations use difference-in-difference modeling among panel households. All estimations control for baseline household size, main respondent's gender, age, education and marital status, strata, household demographic composition, and a vector of cluster level prices.

$* \mathrm{p}<.1$.

$* * \mathrm{p}<.05$.

$* * * \mathrm{p}<.01$

and 7.16 for the treatment group.

Table $4 \mathrm{~b}$ provides a correlation matrix of standard pairwise Pearson's Correlation coefficients using 2013 (baseline) data only. Correlations are in the expected direction but are low (correlation of Food Security score with per capita food consumption expenditure is only 13.6 per cent), suggesting, as we discussed in the previous section, that they are measuring different dimensions of food security.

\subsection{Empirical methods}

We utilize the longitudinal sample (containing two time periods, baseline and follow-up) to conduct a difference-in-differences (DD) analysis to estimate the impact of the program on food security.

$$
\begin{aligned}
Y_{h j t}= & \left.\beta_{0}+\beta_{1} \text { Post }_{t}+\beta_{2} \text { Transfer }_{j}+\beta_{3} \text { (Transfer*Post }\right)_{j t}+\beta_{4} X_{h}+\beta_{5} Z_{h} \\
& +\beta_{6} \text { Strata }_{j}+\beta_{7} \text { Prices }_{j t}+\beta_{8} \text { Week }_{t}+\varepsilon_{h j t}
\end{aligned}
$$

where

$Y_{h t}$ is the food security outcome of interest for household $h$ in Ward $j$ at time $t$;

Post $_{t}$ is an indicator that equals ' 1 ' if the observation comes from the 12-month follow-up;

Transfer ${ }_{j}$ is an indicator that equals ' 1 ' if the household is in a treatment Ward;

$\mathrm{X}$ is a vector of baseline household demographic characteristics such as $\log$ of household size, and the number of people below age 5 , between age $6-17$, between age $18-60$, and those over 60 ;

$\mathrm{Z}$ is a vector of characteristics of the main respondent (typically the actual program beneficiary) which include indicators for if the main respondent is female, widowed, divorced/separated, has attended school, currently attends school, and linear variables for the highest grade attained and age;

Strata are the three indicators of the strata used in selecting Wards (one of which is excluded from the regression);

Prices $_{\mathrm{jt}}$ refer to a vector of cluster-level prices of eight staple items; Week $_{\mathrm{t}}$ is the week in which the household is interviewed.

In this framework the variable of interest is $\beta_{3}$, which represents the DD program impact. Estimation is via Ordinary Least Squares (OLS) with standard errors clustered at the level of the primary sampling unit (Ward). We use baseline values for main respondent characteristics and household demographics, while prices are maintained as exogenous and allowed to vary by time period. We tested separately to see if the program had an inflationary effect in treatment wards and found none, a plausible finding given that the overall coverage of the program is only 10-15 per cent in the ward.

The identifying assumption of the DD model is of 'parallel trends', i.e., the trajectory of the dependent variable over the study time period would be the same across treatment and comparison wards in absence of the program. Since we do not have data across multiple time periods prior to baseline, we have to operate under this assumption. However, as noted earlier, the study design is a Ward level longitudinal matched design. Comparison wards were 'matched' to treatment wards to try to maintain the validity of this assumption. In addition, we have baseline equivalence as demonstrated in Table 3. This is as expected since all households, in both comparison and treatment Wards, have been selected according to the same program eligibility criteria.

The DD model does not control for differences between the treatment and comparison groups on account of household or individual unobserved characteristics. Our impact estimate ( $\beta_{3}$ in the above equation) may be biased if there are unobserved characteristics influencing both the program and our outcome measure. This becomes important when of our outcomes, the Food Security score, is a subjective measure that may also capture the predisposition or attitudinal characteristics of the main respondent. A fixed effects model at the main respondent level can address the issue of unobserved characteristics that are fixed over time as a source for endogeneity, and is therefore our preferred model: 


\begin{tabular}{|c|c|c|c|}
\hline & $\begin{array}{l}\text { (1) } \\
\text { Per capita food consumption }\end{array}$ & $\begin{array}{l}\text { (2) } \\
\text { Household food security score }\end{array}$ & $\begin{array}{l}\text { (3) } \\
\text { Household diet diversity score }\end{array}$ \\
\hline \multicolumn{4}{|l|}{ On the full sample } \\
\hline Impact estimate & $\begin{array}{l}-0.452 \\
(1.486)\end{array}$ & $\begin{array}{l}1.790^{* * *} \\
(0.700)\end{array}$ & $\begin{array}{l}0.673^{k+\ldots \pi x} \\
(0.222)\end{array}$ \\
\hline Follow-up indicator & $\begin{array}{l}-0.582 \\
(5.031)\end{array}$ & $\begin{array}{l}-4.212^{*} \\
(2.303)\end{array}$ & $\begin{array}{l}0.892 \\
(0.800)\end{array}$ \\
\hline Week of interview & $\begin{array}{l}0.077 \\
(0.457)\end{array}$ & $\begin{array}{l}0.675^{k \cdot k+1} \\
(0.216)\end{array}$ & $\begin{array}{l}-0.054 \\
(0.074)\end{array}$ \\
\hline Observations & 4001 & 4001 & 4001 \\
\hline Adjusted R-squared & 0.010 & 0.189 & 0.167 \\
\hline \multicolumn{4}{|c|}{ On small households ( (Household Size $<=4$ members) } \\
\hline Impact estimate & $\begin{array}{l}0.300 \\
(2.662)\end{array}$ & $\begin{array}{l}2.499^{1 . k \times * k} \\
(0.839)\end{array}$ & $\begin{array}{l}0.759^{* * * * *} \\
(0.279)\end{array}$ \\
\hline Follow-up indicator & $\begin{array}{l}-2.383 \\
(9.797)\end{array}$ & $\begin{array}{l}-3.575 \\
(2.867)\end{array}$ & $\begin{array}{l}1.288 \\
(0.994)\end{array}$ \\
\hline Week of interview & $\begin{array}{l}0.151 \\
(0.907)\end{array}$ & $\begin{array}{l}0.552^{2 k x} \\
(0.270)\end{array}$ & $\begin{array}{l}-0.081 \\
(0.088)\end{array}$ \\
\hline Observations & 1970 & 1970 & 1970 \\
\hline Adjusted R-squared & 0.027 & 0.140 & 0.217 \\
\hline
\end{tabular}

Notes: Standard errors clustered at the Ward level in parentheses.

Estimations control for week of interview and a vector of cluster level prices.

$* \mathrm{p}<.1$.

$* * \mathrm{p}<.05$.

$* * * \mathrm{p}<.01$

$Y_{h j t}=\alpha_{h}+\beta_{1}$ Post $_{t}+\beta_{2}$ Transfer $_{j} *$ Post $_{t}+\beta_{3}$ Prices $_{j t}+\beta_{4}$ Week $_{t}+v_{h j t}$

where

$\mathrm{Y}_{\mathrm{hjt}}$ is the food security outcome of interest for mai respondent of household $h$ in Ward $j$ at time $t$.

$\alpha_{\mathrm{h}}(h=1 \ldots \ldots . . \mathrm{H})$ is the intercept for each household (h householdspecific intercepts).

Post, Prices, and Week are as described in Eq. (1).

$\beta_{2}$ represents the impact estimate and $\nu_{\mathrm{ht}}$ is the time-varying error term.

Standard errors are clustered at the ward level.

We estimate Eq. (2) using only the subsample of households where the main respondent has not changed from baseline to follow-up. Over 76 percent of our panel has the same main respondent across the two time periods. Table A2 in the Appendix compares the difference in household characteristics between households with the same main respondent in the two time periods to those where it changed. We find significant differences in that households with the same main respondent tend to be smaller, have higher per capita expenditure and are more likely to female than male. However, within the same-respondent sample, we do not find any significant differences between the treatment and comparison group (Appendix, Table A3).

\subsection{Results and discussion}

Table 5 provides the results of our difference-in-differences model. Given the importance of the week in which the households were interviewed, our difference-in-differences estimates control for week of interview, in addition to the standard set of baseline household demographics and main respondent characteristics, and contemporaneous prices. ${ }^{15}$ Results using the full panel sample are shown in first half of Table 5. We find a statistically significant impact on Food Security and

15 Table A 4 in the Appendix shows the results of the Difference-in-Difference estimates on the full sample without controlling for week. We find significant impacts on Diet Diversity score, but not on per capita food consumption or on the Food Security score.
Diet Diversity scores, which have increased by 1.2 points and 0.77 points. However, the impact estimate of $\$ 1$ on per capita food consumption is not statistically significant.

The HSCT program is designed so that per capita transfer size decreases with household size. However, the transfer size increases proportionally with household members only up to a point (four members) and then remains flat at USD25 for all households greater than four members. Since the median household size in our sample is five, over 50 per cent of households have more than four members. To account for this variation in the intensity of the treatment, we restrict our sample to households with four or fewer residents (bottom panel of Table 5). In this case, we do not find a statistically significant average treatment effect on food consumption value or on the Food Security score.

To control for attitudinal bias in the Food Security score, we restricted the sample to only those households where the main respondent had not changed from 2013 to 2014 and run an individual fixed effects model, which controls for personality traits and other unobserved idiosyncrasies of the individual that are fixed over the oneyear time period. Results are provided in Table 6. The impact estimate on food consumption is again not statistically significant, in both the full panel sample as well as the subsample of smaller households. However, impact estimate on the Food Security and Diet Diversity scores are significant across both samples. The effect sizes are larger for the smaller household sample, particularly in the case of the Food Security score. One reason why we observe this may be because per person value of the transfer is higher in smaller households.

We find a consistent positive impact on the Diet Diversity score across all models in the range of $0.7-0.8$ points. Table 7 provides a list of the 12 foodstuffs that make up the score. We find a 13 percentage point (pp) increase in the number of households consuming fruits, $16 \mathrm{pp}$ increase for pulses and legumes, $13 \mathrm{pp}$ for dairy, $15 \mathrm{pp}$ for fats, $13 \mathrm{pp}$ for sweets and finally about $6 \mathrm{pp}$ for miscellaneous items, which include non-alcoholic beverages and condiments. Why are these increases not consistently reflected in the food consumption measure? One answer is that the value of food consumption variable hides dynamic activity that is taking place within the household as it makes choices to obtain food from different sources. This means that even though the treatment and comparison groups may on average spend roughly the same amount on food, the cash transfer beneficiaries have more cash available. This 
Table 7

Household diet diversity impact estimates.

\begin{tabular}{|c|c|c|c|}
\hline & & Impact Estimate & Baseline Mean \\
\hline \multicolumn{2}{|c|}{ Diet diversity score } & $\begin{array}{l}0.753^{\text {k*kik }} \\
(0.204)\end{array}$ & 6.0 \\
\hline \multicolumn{2}{|c|}{ Presence of food item in diet } & Impact estimate & Baseline mean (\%) \\
\hline (1) & Cereals & $\begin{array}{l}-0.001 \\
(0.001)\end{array}$ & 99.9 \\
\hline (2) & Roots \& tubers & $\begin{array}{l}0.028 \\
(0.053)\end{array}$ & 11.0 \\
\hline (3) & Vegetables & $\begin{array}{l}0.002 \\
(0.007)\end{array}$ & 98.9 \\
\hline (4) & Fruits & $\begin{array}{l}0.129^{k} \\
(0.056)\end{array}$ & 33.5 \\
\hline (5) & Meats & $\begin{array}{l}0.000 \\
(0.040)\end{array}$ & 38.6 \\
\hline (6) & Eggs & $\begin{array}{l}-0.037^{*} \\
(0.019)\end{array}$ & 6.8 \\
\hline (7) & Fish & $\begin{array}{l}0.010 \\
(0.038)\end{array}$ & 22.4 \\
\hline (8) & Pulses \& legumes & $\begin{array}{l}0.159^{* k *} \\
(0.044)\end{array}$ & 57.4 \\
\hline (9) & Dairy & $\begin{array}{l}0.127^{\text {kndk }} \\
(0.041)\end{array}$ & 31.9 \\
\hline (10) & Fats & $\begin{array}{l}0.145^{\text {(2kx }} \\
(0.046)\end{array}$ & 64.0 \\
\hline (11) & Sweets & $\begin{array}{l}0.132^{1 * \times * *} \\
(0.035)\end{array}$ & 46.7 \\
\hline (12) & Misc. (condiments \& beverages) & $\begin{array}{l}0.059^{\text {kn*x }} \\
(0.020)\end{array}$ & 92.5 \\
\hline \multicolumn{2}{|c|}{ No. of observations } & 5244 & 2621 \\
\hline
\end{tabular}

Standard errors clustered at the Ward level in parentheses.

Notes: Attrition-adjusted weighted results. Estimations use difference-in-difference modeling among panel households. All estimations control for week of interview, baseline household size, main respondent's gender, age, education and marital status, strata, household demographic composition, and a vector of cluster level prices.

$* \mathrm{p}<.1$.

$* * \mathrm{p}<.05$.

$* * * \mathrm{p}<.01$

additional cash allows them to: (1) approach the market to diversify their food basket; (2) diversify own-production to other foodstuffs, and; (3) rely less on gifts as a source for their food.

Table 8 provides baseline mean value of consumption for each of the 12 categories that make up the Diet Diversity score and disaggregated by source into own production, market purchases, and gifts. Since these households are subsistence farmers, own production is the primary source of food ( $\sim 57$ per cent), followed by purchases ( $\sim 23$ per cent), and a non-negligible amount ( $\sim 20$ per cent) of food is sourced from gifts (last column of Table 8). Cereal (in particular maize) is the staple food and accounts for 36.6 per cent of total food consumption value, followed by vegetables ( 23 per cent), meats ( 8.4 per cent) and pulses and legumes (eight per cent). Vegetables, fruits, eggs, and dairy are mostly own-produced. Over half of the cereal, roots and tubers, meat,

Table 8

Baseline mean values of total household food consumption value by source.

\begin{tabular}{|c|c|c|c|c|c|c|c|c|}
\hline \multirow[t]{2}{*}{ (1) } & \multirow{2}{*}{$\begin{array}{l}\text { Total } \\
\text { In USD }\end{array}$} & \multirow[b]{2}{*}{$\begin{array}{l}\% \text { Of total } \\
\text { consumption }\end{array}$} & \multicolumn{2}{|c|}{ Own production } & \multicolumn{2}{|c|}{ Purchases } & \multicolumn{2}{|l|}{ Gifts } \\
\hline & & & In USD & $\begin{array}{l}\% \text { Of food item in col } \\
\text { (1) that is produced }\end{array}$ & In USD & $\begin{array}{l}\% \text { Of food item in col (1) } \\
\text { that is purchased }\end{array}$ & In USD & $\begin{array}{l}\% \text { Of food item in } \\
\text { col (1) that is gifted }\end{array}$ \\
\hline Cereals & 29.8 & 36.6 & 16.2 & 54.3 & 7.5 & 25.2 & 6.1 & 20.5 \\
\hline Roots \& Tubers & 0.9 & 1.1 & 0.5 & 52.7 & 0.2 & 22.4 & 0.2 & 25.0 \\
\hline Vegetables & 18.7 & 23.0 & 14.6 & 77.9 & 1.6 & 8.3 & 2.6 & 13.8 \\
\hline Fruits & 2.3 & 2.9 & 1.8 & 76.8 & 0.1 & 5.1 & 0.4 & 18.1 \\
\hline Meats & 6.8 & 8.4 & 3.8 & 56.4 & 1.1 & 16.4 & 1.9 & 27.3 \\
\hline Eggs & 0.2 & 0.3 & 0.2 & 78.6 & 0.0 & 16.2 & 0.0 & 5.3 \\
\hline Fish & 1.2 & 1.5 & 0.2 & 20.2 & 0.7 & 54.7 & 0.3 & 25.1 \\
\hline Pulses \& legumes & 6.6 & 8.1 & 4.5 & 68.2 & 0.3 & 4.6 & 1.8 & 27.2 \\
\hline Dairy & 3.7 & 4.6 & 2.7 & 72.9 & 0.3 & 7.4 & 0.7 & 19.7 \\
\hline Fats & 4.7 & 5.7 & 0.6 & 12.3 & 2.8 & 60.1 & 1.3 & 27.6 \\
\hline Sweets & 2.5 & 3.1 & 0.0 & 0.4 & 2.0 & 78.2 & 0.5 & 21.4 \\
\hline Misc. (condiments \& beverages) & 3.7 & 4.6 & 1.2 & 31.2 & 2.0 & 52.5 & 0.6 & 16.3 \\
\hline Other food & 0.3 & 0.3 & 0.2 & 60.5 & 0.1 & 31.0 & 0.0 & 8.5 \\
\hline Total & 81.6 & 100.0 & 46.4 & 56.9 & 18.6 & 22.8 & 16.5 & 20.2 \\
\hline
\end{tabular}

Notes: Attrition-adjusted weighed means. Total number of observation is 2621 . 
Table 9

Impact estimates on household food expenditure, disaggregated by source (Log of USD).

\begin{tabular}{|c|c|c|c|c|}
\hline & Total & Own & Purchases & Gifts \\
\hline Cereals & $\begin{array}{l}-0.010 \\
(0.047)\end{array}$ & $\begin{array}{l}-0.026 \\
(0.147)\end{array}$ & $\begin{array}{l}0.188^{\text {kste }} \\
(0.089)\end{array}$ & $\begin{array}{l}-0.220^{\text {. }} \\
(0.080)\end{array}$ \\
\hline Roots \& Tubers & $\begin{array}{l}0.073 \\
(0.102)\end{array}$ & $\begin{array}{l}0.041 \\
(0.072)\end{array}$ & $\begin{array}{l}0.043 \\
(0.032)\end{array}$ & $\begin{array}{l}-0.006 \\
(0.039)\end{array}$ \\
\hline Vegetables & $\begin{array}{l}-0.102 \\
(0.071)\end{array}$ & $\begin{array}{l}-0.113 \\
(0.111)\end{array}$ & $\begin{array}{l}0.209^{2} \\
(0.088)\end{array}$ & $\begin{array}{l}-0.102 \\
(0.106)\end{array}$ \\
\hline Fruits & $\begin{array}{l}0.266^{\text {*.x }} \\
(0.115)\end{array}$ & $\begin{array}{l}0.249^{*} \\
(0.117)\end{array}$ & $\begin{array}{l}0.059^{3.6} \\
(0.023)\end{array}$ & $\begin{array}{l}-0.024 \\
(0.036)\end{array}$ \\
\hline Meats & $\begin{array}{l}0.033 \\
(0.109)\end{array}$ & $\begin{array}{l}0.006 \\
(0.088)\end{array}$ & $\begin{array}{l}0.079 \\
(0.066)\end{array}$ & $\begin{array}{l}-0.091 \\
(0.060)\end{array}$ \\
\hline Eggs & $\begin{array}{c}-0.040 \\
(0.025)\end{array}$ & $\begin{array}{c}-0.009 \\
(0.022)\end{array}$ & $\begin{array}{l}-0.020 \\
(0.015)\end{array}$ & $\begin{array}{l}-0.011^{*} \\
(0.006)\end{array}$ \\
\hline Fish & $\begin{array}{c}-0.009 \\
(0.070)\end{array}$ & $\begin{array}{c}-0.027 \\
(0.030)\end{array}$ & $\begin{array}{l}0.044 \\
(0.054)\end{array}$ & $\begin{array}{l}-0.013 \\
(0.031)\end{array}$ \\
\hline Pulses \& Legumes & $\begin{array}{l}0.400^{\text {nat }} \\
(0.111)\end{array}$ & $\begin{array}{l}0.331 \\
(0.115)\end{array}$ & $\begin{array}{l}0.021 \\
(0.029)\end{array}$ & $\begin{array}{l}0.090 \\
(0.073)\end{array}$ \\
\hline Dairy & $\begin{array}{l}0.227^{* *} \\
(0.096)\end{array}$ & $\begin{array}{l}0.122 \\
(0.066)\end{array}$ & $\begin{array}{l}0.040 \\
(0.040)\end{array}$ & $\begin{array}{l}0.054 \\
(0.049)\end{array}$ \\
\hline Fats & $\begin{array}{l}0.314^{4} \\
(0.084)\end{array}$ & $\begin{array}{l}0.056 \\
(0.040)\end{array}$ & $\begin{array}{l}0.322^{\text {na }} \\
(0.081)\end{array}$ & $\begin{array}{l}-0.050 \\
(0.041)\end{array}$ \\
\hline Sweets & $\begin{array}{l}0.207^{\text {takt }} \\
(0.058)\end{array}$ & $\begin{array}{l}0.007 \\
(0.006)\end{array}$ & $\begin{array}{l}0.286^{\text {nes }} \\
(0.059)\end{array}$ & $\begin{array}{l}-0.082^{* k} \\
(0.036)\end{array}$ \\
\hline Misc. (Condiments \& Beverages) & $\begin{array}{l}0.116 \\
(0.067)\end{array}$ & $\begin{array}{l}0.022 \\
(0.052)\end{array}$ & $\begin{array}{l}0.209^{2} \\
(0.056)\end{array}$ & $\begin{array}{l}-0.101 \\
(0.041)\end{array}$ \\
\hline Total & $\begin{array}{l}0.079 \\
(0.054)\end{array}$ & $\begin{array}{l}0.063 \\
(0.082)\end{array}$ & $\begin{array}{l}0.367^{2} \\
(0.070)\end{array}$ & $\begin{array}{l}-0.251^{\text {t.k }} \\
(0.105)\end{array}$ \\
\hline
\end{tabular}

Notes: Attrition-adjusted weighted results. Standard errors clustered at the Ward level in parentheses.

Estimations use difference-in-difference modeling among 5244 panel households. All estimations control for week of interview, baseline household size, main respondent's gender, age, education and marital status, strata, household demographic composition, and a vector of cluster level prices.

$* \mathrm{p}<.1$.

$* * \mathrm{p}<.05$.

$* * * \mathrm{p}<.01$.

and pulses consumption expenditure are from own-production. Fish, fats, sweets, and miscellaneous items are mostly purchased from the market. There is less variation in gifts, which account for about 20 per cent of consumption for most food items.

Table 9 provides impact estimates on each of these 12 categories, disaggregated by their source. Since cereal (maize) is the main staple food, we first look at cereals in the first row. We find that though there is no significant impact on value of total cereal consumption, there is significant activity behind this aggregate measure. The cash transfer has led to a 19 per cent increase in purchases of cereals. Almost all of it however is offset by a 22 per cent reduction in gifts. Similarly, though there is no overall impact on value of vegetable consumption, we find vegetable purchases have increased by 21 per cent, though most of this may be offset by a reduction in vegetable production and gifts. We also find a 27 per cent increase in consumption of fruits, composed of increases in own-production and purchases. Fats and sweets follow a similar pattern with significant increases in consumption, derived from market purchases. There is also a 40 per cent increase in value of pulses and legumes consumption, stemming from a 33 per cent increase in own production. These findings indicate that these households are diversifying production away from cereals to pulses and legumes, and fruits. Dairy follows a similar pattern to that of pulses - the impact estimate on total consumption value is 23 per cent, with most of it composed from an increase in own-production. Interestingly, gifts as a source of food have significantly reduced across several foodstuffs. The last row provides impact estimates on household aggregate food consumption. While there is no impact on value of aggregate food consumption, this result hides the 37 per cent increase in purchases (significant at the one percent level) and 25 per cent decline in gifts (significant at the five percent level).

We see these results reflected in the qualitative data that was also collected as part of the impact evaluation at follow-up. Qualitative data consisted of in-depth interviews with eight caregivers and nine youths in beneficiary households, semi-structured interviews with government officials and focus group discussions with key community members (American Institutes for Research, 2014). A key theme emerging across all interviews and discussions was that the cash transfer was useful in obtaining food and in purchasing livestock (mainly goats). As one caregiver in Mwenezi reported:

I am paying school fees, buying food and we are planning with other beneficiaries to do mukando so that we can serve and buy something big at the like goats. At the moment I haven't yet bought any livestock because of school fees and food.......I think these transfers are very much helpful in our lives because a lot has changed for the better like having toiletries, school shoes and mainly food is now on our tables. There is a great change in my relationship with the family because if you receive your transfer and you bring sugar to your family they become happy and also when relatives visit they can now drink tea and they feel important whenever they receive such a welcome from someone who didn't manage to feed a visitor before.

Apart from obtaining more food, several others commented on how they were able to buy different foodstuffs and items that they earlier could not afford:

I have knowledge on how these transfers are managed because my mother is a beneficiary and she is the one who make all the decisions on how this money is used. My mother bought a goat from her savings and I really appreciate because since we started receiving these transfers my mother bought me books and at times paid for my school fees and there is a big change on our daily food stuffs. (Youth Interview, Binga)

I know about the program and that my family receives the money...I do not know who takes charge of how we use the money between my Aunt and Uncle. All I know is that they buy groceries for the family, things like sugar and mealie-meal. (Youth Interview, Binga) 
As compared to last year, my household duties have increased as I now own a garden after buying seeds using HSCT cash...Everytime I receive HSCT cash, I use the money to buy and sell kapenta fish in and around the village for both cash and barter trading with maize or mhunga grain. This I do to ensure that the money is multiplied so that it can be able to cover fees for all my boys. (Caregiver Interview, Binga)

\section{Conclusion and Policy implications}

\subsection{Conclusions}

We analyzed determinants of household food security and food consumption, and find that variables indicative of vulnerability, such as being labor constrained, not having planted a crop last season, relying on maricho/casual labor, or having suffered from an income shock, are important in explaining variation in the Food Security score but do not explain variation in value of food consumption. The common theme across these variables is that they capture some of the uncertainty these households face with respect to food access. However, physical assets, household amenities, a steady wage, and monthly remittances explained variation in both value of food consumption and the Food Security score. We complement this analysis by comparing households that were interviewed during two different periods of time, one period which induced greater vulnerability than the other, to understand which factors play a protective role and which ones get accentuated during tough periods. Here we find that being labor constrained weakened food security, but has no impact on value of food consumption in the pre-harvest period. This evidence supports the program feature of the HSCT wherein eligibility of a household to become a beneficiary of the cash transfer is determined not just by poverty but also by its dependency ratio, a proxy for labor constraints status. Given the current drought and food security crisis in Zimbabwe, social protection programs, such as the HSCT and their methodology for identifying beneficiaries, assume even more importance.

Our impact analysis of the HSCT program on food security and consumption supports the notion that relying on an aggregate food consumption measure is inadequate in assessing food security. Our models do not indicate impacts on aggregate food consumption but there are statistically significant impacts on the Food Security and Diet Diversity scores across all models. This is because aggregate food consumption hides dynamic activity that is taking place within the household that produces robust results for household diet diversity. These labor-constrained and food-poor households depend on subsistence farming and gifts and aid to make up their total food basket. The cash transfer enables them to make market purchases to diversify their diet (market purchases increase by 37 percent), rely less on gifts and aid (reduction of 25 per cent), as well as diversify their own production to dairy, pulse, legumes, and fruits.

\subsection{Limitations}

These results have to be read keeping in mind limitations of our study design. This is not a randomized controlled study and as a result Wards were not randomized within each stratum. Comparison and Treatment Wards are located in different districts within each stratum. While this has the advantage of reducing spillover effects, these geographical differences may hide unobserved differences. However, Comparison Wards are both geographically adjacent and explicitly matched to Treatment Wards. In addition, we run a difference-in-differences model, which accounts for baseline differences between the two groups. We cannot confirm the main identifying assumption of parallel trends for our DD model, since we do not have multiple prebaseline data points. However, the fact that we have baseline equivalence on not just the outcomes but also household characteristics that would determine trends in consumption and food security suggest that this assumption is plausible. One other threat to internal validity may come from the fact that households may move to treatment areas. However, there is no ongoing enrollment, so this mitigates the threat of self-selection into the treatment group.

\subsection{Policy implications}

Our paper has important policy implications. The right to food is recognized in Article 25 of the Universal Declaration on Human Rights and Article 11 of the International Covenant on Economic, Social and Cultural Rights. While progress has been made, about 800 million people are still chronically undernourished, and one in four people remain undernourished in sub-Saharan Africa (FAO, IFAD and WFP, 2014). To accurately monitor progress, we will need to rely on multiple measures of food security, which include measures that capture the uncertainty and mental stress associated with food access. A measure such as value of household food consumption does not provide us with the complete picture of the household's vulnerability with respect to food. This paper builds on previous research by providing evidence of the multidimensionality of food security and subsequently the usefulness of relying on a combination of measures to assess failure/success of a program/policy instrument. Our ability to do this within the context of a large government program whose objective is to address food security enhances the external validity of the results. Our findings also underline the important practice of utilizing labor-constrained status as an attribute for identifying program beneficiaries.

\section{Acknowledgements}

This study analyzes data collected for a comprehensive evaluation of Zimbabwe's Harmonized Social Cash Transfer (HSCT) Programme. The evaluation was being conducted by the American Institutes for Research (AIR) and the University of North Carolina at Chapel Hill for the Government of Zimbabwe, under contract to UNICEF. The members of the evaluation team, listed by affiliation and then alphabetically within affiliation are: American Institutes for Research (Andi Coombes, Thomas de Hoop, Cassandra Jessee, Leah Prencipe, Hannah Reeves, David Seidenfeld, Rosa Castro Zarzur); Centre of Applied Social Sciences (CASS), Zimbabwe (Billy Mukamuri); FAO (Silvio Diadone, Benjamin Davis); Ministry of Public Service, Labour, and Social Welfare, Government of Zimbabwe (Sydney G. Mhishi, Lovemore Dumba); Ruzivo Trust (Prosper Mutondi); UNICEF Office of Research Innocenti (Sudhanshu Handa, Tia Palermo, Amber Peterman, Leah Prencipe); UNICEF-Zimbabwe (Leon Muwoni, Lauren Rumble, Elayn Sammon) and University of North Carolina at Chapel Hill (Sarah Abdoulayi, Gustavo Angeles, Garima Bhalla, Sudhanshu Handa, Mary Jane Hill, Adria Molotsky, Frank Otchere). We acknowledge the patience exercised by the Zimbabwean households during interviews and the input and dedication of the team of supervisors, enumerators, and drivers from CASS and Ruzivo Trust during data collection.

We are grateful to Jeremy Moulton and Christine Durrance (Department of Public Policy, University of North Carolina, Chapel Hill) for the feedback they provided on earlier drafts of this paper.

Ethics Approval

The study was approved by the Medical Research Council of Zimbabwe (MRCZ) and the Institutional Review Board of the American Institutes for Research.

\section{Funding}

This work was supported by UNICEF [431-23421]. 
Appendix A

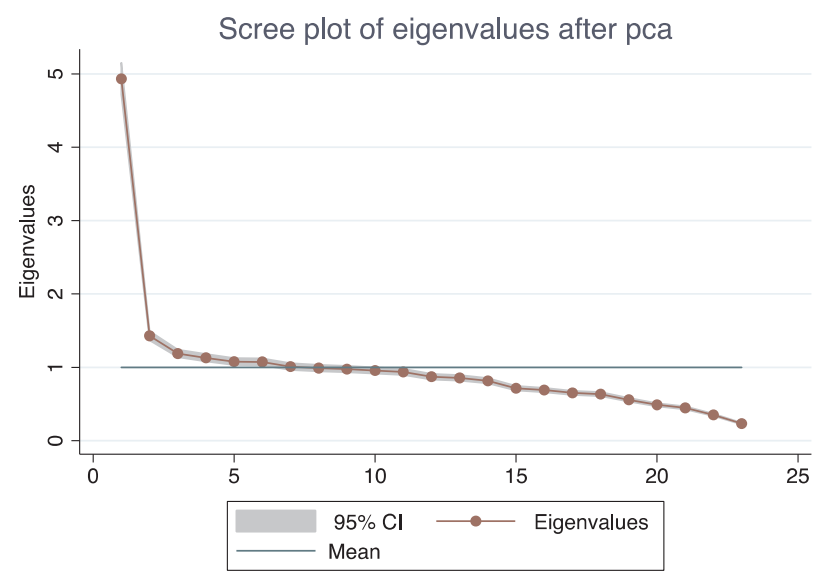

Fig. A1a. Scree Plot after PCA for Productive Assets Owned by the household.

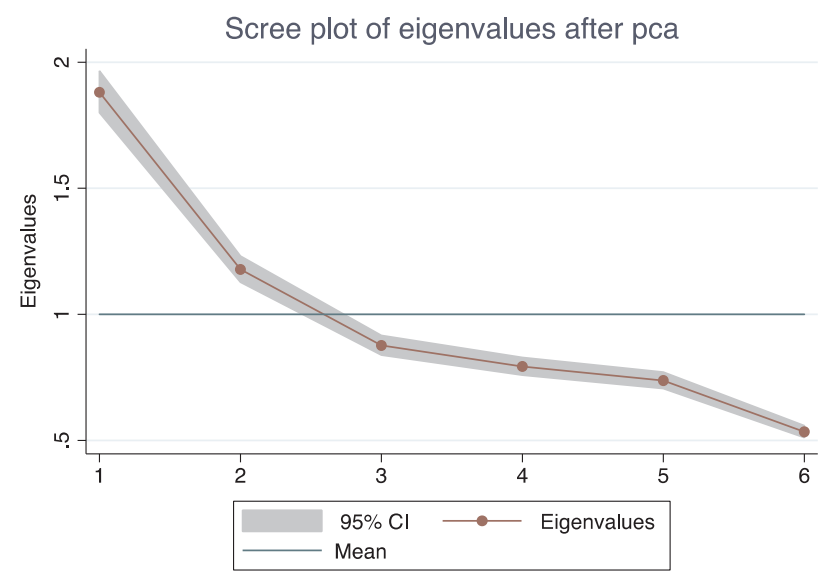

Fig. A1b. Scree Plot after PCA for household amenities.

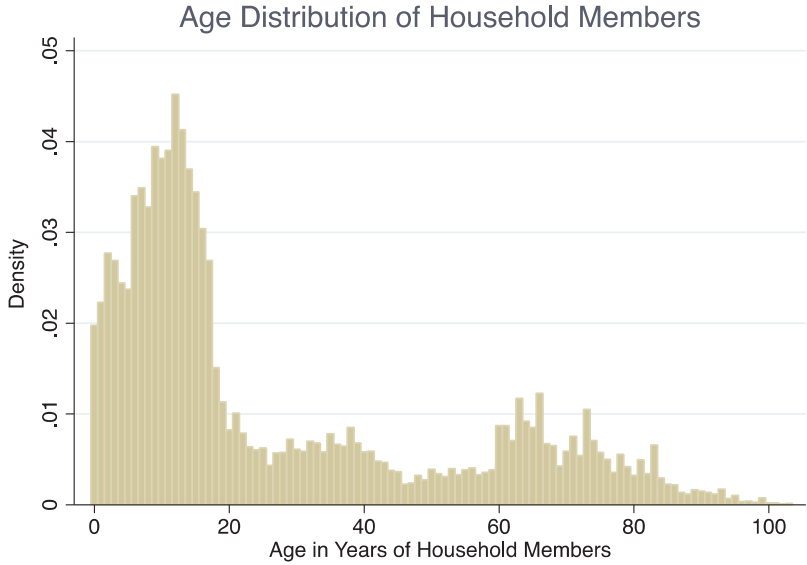

Fig. A2. Age distribution of household members.

Distribution of Food Security Score and Food Consumption Across Baseline and Follow-up
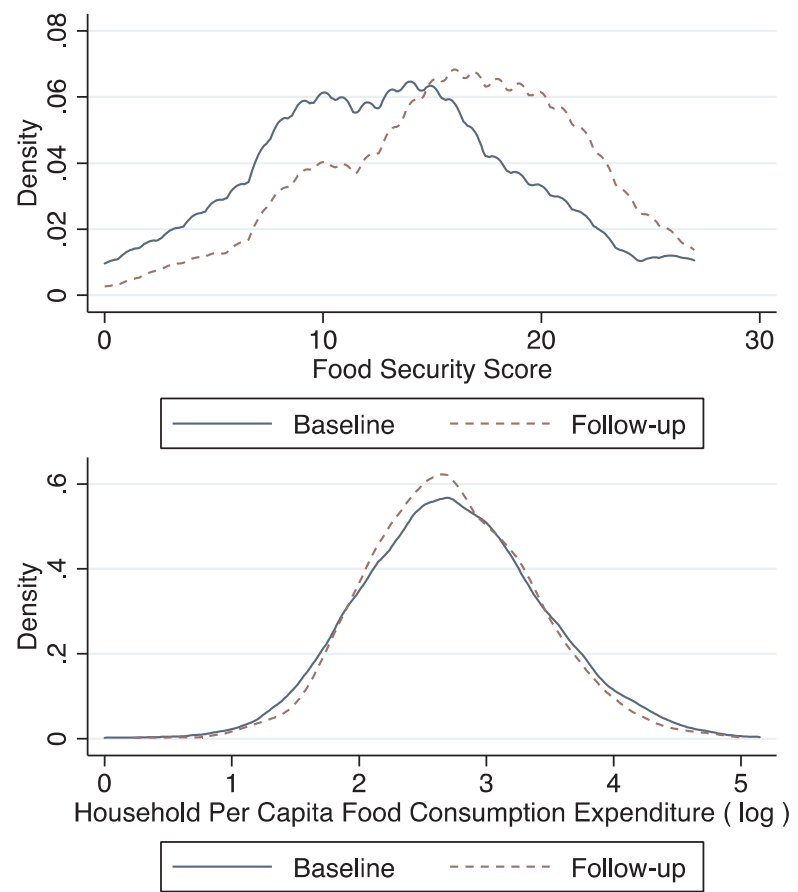

Fig. A3. Kernel densities of household food security and food consumption. 
Table A1

Full results from interacted model comparing pre/initial harvest vs. peak harvest.

\begin{tabular}{|c|c|c|c|c|}
\hline & \multicolumn{2}{|c|}{$\begin{array}{l}\text { (1) } \\
\text { Food security score }\end{array}$} & \multicolumn{2}{|c|}{$\begin{array}{l}\text { Log P.C. food consumption } \\
\text { Log }\end{array}$} \\
\hline & Estimate & Interacted estimate & Estimate & Interacted estimate \\
\hline Pre/initial harvest dummy & $\begin{array}{l}5.799^{*} \\
(3.092)\end{array}$ & & $\begin{array}{l}-0.104 \\
(0.267)\end{array}$ & \\
\hline \multicolumn{5}{|l|}{ Household demographics: } \\
\hline Household size (log) & $\begin{array}{l}-0.036 \\
(1.136)\end{array}$ & $\begin{array}{l}1.682 \\
(1.710)\end{array}$ & $\begin{array}{l}-1.499^{* k * k} \\
(0.196)\end{array}$ & $\begin{array}{l}0.090 \\
(0.245)\end{array}$ \\
\hline \# Children under 5 & $\begin{array}{l}-0.277 \\
(0.332)\end{array}$ & $\begin{array}{l}-0.233 \\
(0.452)\end{array}$ & $\begin{array}{l}0.098^{* *} \\
(0.049)\end{array}$ & $\begin{array}{l}-0.056 \\
(0.076)\end{array}$ \\
\hline \# Children 6-17 & $\begin{array}{l}-0.469^{* * \hbar} \\
(0.211)\end{array}$ & $\begin{array}{l}0.157 \\
(0.296)\end{array}$ & $\begin{array}{l}0.081^{* *} \\
(0.039)\end{array}$ & $\begin{array}{l}-0.019 \\
(0.049)\end{array}$ \\
\hline \# Adults 18-59 & $\begin{array}{l}0.103 \\
(0.340)\end{array}$ & $\begin{array}{l}-0.903^{* *} \\
(0.447)\end{array}$ & $\begin{array}{l}0.098^{* * * *} \\
(0.032)\end{array}$ & $\begin{array}{l}0.027 \\
(0.041)\end{array}$ \\
\hline \# Elderly (> 60) & $\begin{array}{l}0.003 \\
(0.378)\end{array}$ & $\begin{array}{l}-0.604 \\
(0.531)\end{array}$ & $\begin{array}{l}0.112^{k *} \\
(0.052)\end{array}$ & $\begin{array}{l}-0.069 \\
(0.078)\end{array}$ \\
\hline \multicolumn{5}{|l|}{ Main respondent characteristics } \\
\hline Female & $\begin{array}{l}-0.680 \\
(0.343)\end{array}$ & $\begin{array}{l}-0.344 \\
(0.645)\end{array}$ & $\begin{array}{l}-0.084 \\
(0.044)\end{array}$ & $\begin{array}{l}0.003 \\
(0.068)\end{array}$ \\
\hline Age & $\begin{array}{l}-0.029 \\
(0.019)\end{array}$ & $\begin{array}{l}0.005 \\
(0.025)\end{array}$ & $\begin{array}{l}-0.002 \\
(0.002)\end{array}$ & $\begin{array}{l}0.001 \\
(0.002)\end{array}$ \\
\hline Widowed $($ Yes = 1) & $\begin{array}{l}0.128 \\
(0.456)\end{array}$ & $\begin{array}{l}-0.248 \\
(0.778)\end{array}$ & $\begin{array}{l}0.067 \\
(0.063)\end{array}$ & $\begin{array}{l}-0.123 \\
(0.089)\end{array}$ \\
\hline Divorced/separated (Yes = 1) & $\begin{array}{l}0.915 \\
(0.621)\end{array}$ & $\begin{array}{l}-0.250 \\
(0.878)\end{array}$ & $\begin{array}{l}0.046 \\
(0.067)\end{array}$ & $\begin{array}{l}-0.055 \\
(0.111)\end{array}$ \\
\hline Attended school (Yes = 1) & $\begin{array}{l}0.234 \\
(0.598)\end{array}$ & $\begin{array}{l}0.271 \\
(0.708)\end{array}$ & $\begin{array}{l}0.064 \\
(0.048)\end{array}$ & $\begin{array}{l}0.008 \\
(0.070)\end{array}$ \\
\hline \multicolumn{5}{|l|}{ Other socio-economic characteristics } \\
\hline Distance to food market & $\begin{array}{l}-0.100 \\
(0.042)\end{array}$ & $\begin{array}{l}0.099^{*} \\
(0.054)\end{array}$ & $\begin{array}{l}0.005^{*} \\
(0.003)\end{array}$ & $\begin{array}{l}-0.011 \\
(0.006)\end{array}$ \\
\hline Distance to input market & $\begin{array}{l}0.038^{k n k x} \\
(0.013)\end{array}$ & $\begin{array}{l}-0.035 \\
(0.020)\end{array}$ & $\begin{array}{l}0.000 \\
(0.001)\end{array}$ & $\begin{array}{l}-0.000 \\
(0.001)\end{array}$ \\
\hline Distance to water source & $\begin{array}{l}0.024 \\
(0.170)\end{array}$ & $\begin{array}{l}-0.144 \\
(0.204)\end{array}$ & $\begin{array}{l}-0.019^{*} \\
(0.011)\end{array}$ & $\begin{array}{l}0.003 \\
(0.022)\end{array}$ \\
\hline Productive assets score & $\begin{array}{l}0.518^{\text {(0.162) }} \\
(0.162)\end{array}$ & $\begin{array}{l}-0.250 \\
(0.229)\end{array}$ & $\begin{array}{l}0.070^{\text {* }} \\
(0.011)\end{array}$ & $\begin{array}{l}-0.014 \\
(0.019)\end{array}$ \\
\hline Household amenities score & $\begin{array}{l}0.660^{\text {thes }} \\
(0.188)\end{array}$ & $\begin{array}{l}-0.172 \\
(0.240)\end{array}$ & $\begin{array}{l}0.052^{\text {*kek }} \\
(0.015)\end{array}$ & $\begin{array}{c}-0.027 \\
(0.020)\end{array}$ \\
\hline \# of livestock type & $\begin{array}{l}0.078 \\
(0.166)\end{array}$ & $\begin{array}{l}0.115 \\
(0.262)\end{array}$ & $\begin{array}{l}0.036^{* * k \times k} \\
(0.012)\end{array}$ & $\begin{array}{l}0.013 \\
(0.019)\end{array}$ \\
\hline Any income from wage labor? $($ Yes $=1)$ & $\begin{array}{l}1.893^{2 x} \\
(0.724)\end{array}$ & $\begin{array}{l}0.209 \\
(0.868)\end{array}$ & $\begin{array}{l}0.137^{\text {*ke }} \\
(0.059)\end{array}$ & $\begin{array}{l}0.029 \\
(0.101)\end{array}$ \\
\hline Any income from maricho labor? (Yes = 1) & $\begin{array}{l}-0.281 \\
(0.527)\end{array}$ & $\begin{array}{l}-1.410^{\text {(2* }} \\
(0.632)\end{array}$ & $\begin{array}{l}0.071^{*} \\
(0.042)\end{array}$ & $\begin{array}{l}-0.046 \\
(0.062)\end{array}$ \\
\hline Planted crops last rainy season $($ Yes $=1)$ & $\begin{array}{l}2.174^{\text {(2x) }} \\
(0.665)\end{array}$ & $\begin{array}{l}-1.206 \\
(1.147)\end{array}$ & $\begin{array}{l}-0.042 \\
(0.070)\end{array}$ & $\begin{array}{l}0.037 \\
(0.100)\end{array}$ \\
\hline Labor constrained $($ Yes $=1)$ & $\begin{array}{l}0.784 \\
(0.700)\end{array}$ & $\begin{array}{l}-3.422^{* \ldots+k} \\
(1.060)\end{array}$ & $\begin{array}{l}0.010 \\
(0.064)\end{array}$ & $\begin{array}{l}0.066 \\
(0.075)\end{array}$ \\
\hline Aid received (in USD) & $\begin{array}{l}-0.004^{*} \\
(0.002)\end{array}$ & $\begin{array}{l}0.004 \\
(0.002)\end{array}$ & $\begin{array}{l}-0.000 \\
(0.000)\end{array}$ & $\begin{array}{l}0.001^{* *} \\
(0.000)\end{array}$ \\
\hline Monthly remittances low ( $<\$ 25 /$ month) & $\begin{array}{l}-0.317 \\
(0.774)\end{array}$ & $\begin{array}{l}-2.709^{* *} \\
(1.071)\end{array}$ & $\begin{array}{l}-0.141^{\text {t*k }} \\
(0.070)\end{array}$ & $\begin{array}{l}-0.099 \\
(0.081)\end{array}$ \\
\hline Has loan outstanding (Yes = 1) & $\begin{array}{l}-1.013^{*} \\
(0.606)\end{array}$ & $\begin{array}{l}1.286 \\
(1.214)\end{array}$ & $\begin{array}{l}0.136^{\text {*ke }} \\
(0.068)\end{array}$ & $\begin{array}{l}0.039 \\
(0.162)\end{array}$ \\
\hline Suffered from a shock? (Yes = 1) & $\begin{array}{l}-1.056 \\
(0.756)\end{array}$ & $\begin{array}{l}-0.632 \\
(0.985)\end{array}$ & $\begin{array}{l}0.027 \\
(0.063)\end{array}$ & $\begin{array}{l}-0.132 \\
(0.083)\end{array}$ \\
\hline Other covariates & & & & \\
\hline Masvingo & $\begin{array}{l}-0.448 \\
(0.628)\end{array}$ & $\begin{array}{l}-1.240 \\
(0.856)\end{array}$ & $\begin{array}{l}0.209^{\text {*2. }} \\
(0.046)\end{array}$ & $\begin{array}{l}0.149^{\text {k* }} \\
(0.073)\end{array}$ \\
\hline Constant & $\begin{array}{l}15.191^{* * k *} \\
(2.559)\end{array}$ & & $\begin{array}{l}4.795^{\text {. }} \\
(0.234)\end{array}$ & \\
\hline Observations & 2121 & & 2121 & \\
\hline
\end{tabular}

Notes: Standard errors in parentheses, clustered at the ward level. Standardized baseline weights utilized. Mashonaland observations not included.

$* \mathrm{p}<.1$.

$* * \mathrm{p}<.05$.

$* * * \mathrm{p}<.01$ 
Table A2

Baseline mean characteristics of panel households - by same/different main respondent.

\begin{tabular}{|c|c|c|c|c|c|}
\hline & \multicolumn{2}{|c|}{ Same respondent both periods } & \multicolumn{2}{|c|}{$\begin{array}{l}\text { Different main respondent at } \\
\text { followup }\end{array}$} & \multirow[t]{2}{*}{$\begin{array}{l}p \text {-Value: comparing } \\
\text { both groups }\end{array}$} \\
\hline & Mean & Std. Error & Mean & Std. Error & \\
\hline \multicolumn{6}{|l|}{ Household demographics } \\
\hline Household size & 4.69 & 0.11 & 6.13 & 0.18 & 0.000 \\
\hline \# Children under 5 & 0.71 & 0.03 & 0.95 & 0.07 & 0.001 \\
\hline \# Children 6-17 & 2.06 & 0.07 & 2.70 & 0.11 & 0.000 \\
\hline \# Adults 18-59 & 1.09 & 0.04 & 1.60 & 0.09 & 0.000 \\
\hline \# Elderly $(>60)$ & 0.83 & 0.03 & 0.88 & 0.05 & 0.304 \\
\hline$\%$ households that have disabled members & 26.38 & 0.01 & 25.47 & 0.02 & 0.751 \\
\hline$\%$ households that have chronically ill members & 36.00 & 0.01 & 39.90 & 0.02 & 0.096 \\
\hline$\%$ households that have elderly members & 65.73 & 0.02 & 60.06 & 0.03 & 0.108 \\
\hline \multicolumn{6}{|l|}{ Main respondent characteristics } \\
\hline$\%$ Female & 73.94 & 0.01 & 52.82 & 0.02 & 0.000 \\
\hline Age & 57.87 & 0.79 & 51.81 & 1.00 & 0.000 \\
\hline$\%$ Widowed & 42.78 & 0.02 & 20.76 & 0.02 & 0.000 \\
\hline \% Divorced/Separated & 9.94 & 0.01 & 6.84 & 0.01 & 0.025 \\
\hline$\%$ Main resp. has schooling & 53.99 & 0.02 & 66.37 & 0.03 & 0.000 \\
\hline$\%$ Main resp. currently attends school & 1.07 & 0.00 & 2.95 & 0.01 & 0.019 \\
\hline Highest grade of Main resp. & 3.08 & 0.12 & 4.13 & 0.15 & 0.000 \\
\hline \multicolumn{6}{|l|}{ Household characteristics } \\
\hline Monthly per capita total expenditure (in usd) & 33.66 & 1.04 & 28.94 & 1.08 & 0.002 \\
\hline Monthly per capita food expenditure (in usd) & 21.04 & 0.78 & 18.85 & 1.00 & 0.077 \\
\hline HFIAS score $(1-27)$ & 14.16 & 0.22 & 13.56 & 0.40 & 0.152 \\
\hline Diet diversity score (1-10) & 5.97 & 0.10 & 6.23 & 0.12 & 0.025 \\
\hline Distance to food market $(\mathrm{km})$ & 3.76 & 0.24 & 3.61 & 0.25 & 0.582 \\
\hline Distance to input market (km) & 19.21 & 1.21 & 19.41 & 1.69 & 0.877 \\
\hline Distance to Water Source $(\mathrm{km})$ & 1.26 & 0.08 & 1.59 & 0.15 & 0.001 \\
\hline \# of livestock type & 2.10 & 0.06 & 2.60 & 0.11 & 0.000 \\
\hline$\%$ households that receive wages & 9.66 & 0.01 & 12.78 & 0.02 & 0.101 \\
\hline$\%$ households undertaking casual/maricho labor & 43.59 & 0.02 & 56.63 & 0.03 & 0.000 \\
\hline$\%$ households that planted crops last season & 88.18 & 0.01 & 91.94 & 0.02 & 0.064 \\
\hline$\%$ households categorized as labor constrained & 84.90 & 0.01 & 80.13 & 0.02 & 0.029 \\
\hline Aid received (in USD) & 59.58 & 4.89 & 65.93 & 7.03 & 0.251 \\
\hline$\%$ of households that have an outstanding loan & 8.94 & 0.01 & 10.01 & 0.02 & 0.653 \\
\hline$\%$ households that have suffered from a shock & 88.94 & 0.01 & 89.55 & 0.01 & 0.689 \\
\hline $\mathrm{N}$ & 1998 & & 621 & & \\
\hline
\end{tabular}

Notes: Attrition-adjusted weighted results. 
Table A3

Baseline mean characteristics of same respondent households - by treatment/comparison.

\begin{tabular}{|c|c|c|c|c|c|}
\hline & \multicolumn{2}{|c|}{ Comparisom group } & \multicolumn{2}{|c|}{ Treatment group } & \multirow[t]{2}{*}{ p-Value: comparing both groups } \\
\hline & Mean & Std. Error & Mean & Std. Error & \\
\hline \multicolumn{6}{|l|}{ Household demographics } \\
\hline Household size & 4.77 & 0.17 & 4.66 & 0.13 & 0.620 \\
\hline \# Children under 5 & 0.76 & 0.05 & 0.69 & 0.04 & 0.360 \\
\hline \# Children 6-17 & 2.05 & 0.11 & 2.07 & 0.08 & 0.916 \\
\hline \# Adults 18-59 & 1.13 & 0.07 & 1.07 & 0.05 & 0.462 \\
\hline \# Elderly $(>60)$ & 0.82 & 0.05 & 0.83 & 0.03 & 0.861 \\
\hline$\%$ households that have disabled members & 28.69 & 0.03 & 25.48 & 0.02 & 0.359 \\
\hline$\%$ households that have chronically ill members & 36.16 & 0.03 & 35.94 & 0.01 & 0.942 \\
\hline$\%$ households that have elderly members & 66.17 & 0.03 & 65.55 & 0.02 & 0.859 \\
\hline \multicolumn{6}{|l|}{ Main respondent characteristics } \\
\hline$\%$ Female & 72.29 & 0.03 & 74.58 & 0.02 & 0.462 \\
\hline Age & 57.68 & 1.36 & 57.95 & 0.96 & 0.882 \\
\hline$\%$ Widowed & 43.53 & 0.02 & 42.49 & 0.02 & 0.731 \\
\hline \% Divorced/Separated & 10.31 & 0.01 & 9.80 & 0.01 & 0.757 \\
\hline$\%$ Main resp. has schooling & 57.97 & 0.03 & 52.44 & 0.02 & 0.114 \\
\hline$\%$ Main resp. currently attends school & 0.39 & 0.00 & 1.33 & 0.00 & 0.042 \\
\hline Highest grade of Main resp. & 3.24 & 0.18 & 3.02 & 0.15 & 0.365 \\
\hline \multicolumn{6}{|l|}{ Household characteristics } \\
\hline Monthly per capita total expenditure (in usd) & 34.01 & 1.87 & 33.52 & 1.25 & 0.831 \\
\hline Monthly Per capita food expenditure (in usd) & 20.76 & 1.19 & 21.15 & 0.98 & 0.798 \\
\hline HFIAS score $(1-27)$ & 13.85 & 0.46 & 14.28 & 0.25 & 0.426 \\
\hline Diet diversity score $(1-10)$ & 6.21 & 0.18 & 5.88 & 0.12 & 0.132 \\
\hline Distance to food market $(\mathrm{km})$ & 3.51 & 0.59 & 3.86 & 0.25 & 0.578 \\
\hline Distance to input market (km) & 19.90 & 2.16 & 18.94 & 1.45 & 0.714 \\
\hline Distance to water source $(\mathrm{km})$ & 1.26 & 0.19 & 1.25 & 0.09 & 0.970 \\
\hline \# of livestock type & 2.11 & 0.07 & 2.10 & 0.08 & 0.957 \\
\hline$\%$ households that receive wages & 9.66 & 0.01 & 9.65 & 0.01 & 0.991 \\
\hline$\%$ households undertaking casual/maricho labor & 46.51 & 0.04 & 42.45 & 0.02 & 0.323 \\
\hline$\%$ households that planted crops last season & 87.31 & 0.02 & 88.52 & 0.01 & 0.628 \\
\hline$\%$ households categorized as labor constrained & 84.83 & 0.02 & 84.93 & 0.01 & 0.956 \\
\hline Aid received (in USD) & 76.34 & 13.64 & 53.06 & 3.73 & 0.104 \\
\hline$\%$ of households that have an outstanding loan & 8.60 & 0.01 & 9.08 & 0.01 & 0.786 \\
\hline$\%$ households that have suffered from a shock & 85.84 & 0.02 & 90.15 & 0.01 & 0.137 \\
\hline $\mathrm{N}$ & 652 & & 1346 & & \\
\hline
\end{tabular}

Notes: Attrition-adjusted weighted results.

Table A4

Difference-in-difference model: impact of the cash transfer on food security measures (without controlling for week of interview).

\begin{tabular}{|c|c|c|c|}
\hline & $\begin{array}{l}\text { (1) } \\
\text { Per capita food consumption }\end{array}$ & $\begin{array}{l}\text { (2) } \\
\text { Household food security score }\end{array}$ & $\begin{array}{l}\text { (3) } \\
\text { Household diet diversity score }\end{array}$ \\
\hline \multirow[t]{2}{*}{ Impact estimate } & 0.651 & 0.043 & $0.701^{\text {knkex }}$ \\
\hline & (1.137) & $(0.570)$ & $(0.193)$ \\
\hline \multirow[t]{2}{*}{ Treatment Indicator } & -0.316 & 0.229 & -0.181 \\
\hline & $(0.930)$ & $(0.436)$ & $(0.124)$ \\
\hline \multirow[t]{2}{*}{ Follow-up Indicator } & $-1.883^{*}$ & $3.169^{k / k+k}$ & $0.432^{\text {knk }}$ \\
\hline & $(1.002)$ & $(0.488)$ & $(0.176)$ \\
\hline Observations & 5244 & 5244 & 5244 \\
\hline Adjusted R-squared & 0.322 & 0.109 & 0.191 \\
\hline
\end{tabular}

Notes: Standard errors clustered at the Ward level in parentheses.

Estimations use difference-in-difference modeling among panel households. All estimations control for baseline household size, main respondent's gender, age, education and marital status, strata, household demographic composition, and a vector of cluster level prices.

$* \mathrm{p}<.1$.

$* * \mathrm{p}<.05$.

$* * * \mathrm{p}<.01$

\section{References}

Adato, M., Bassett, L., 2008. What is the potential of cash transfers to strengthen families affected by HIV and AIDS? A review of the evidence on impacts and key policy debates. Joint Learning Initiative on Children and AIDS, Boston, MA.

Alinovi, L., Mane, E., Romano, D., 2009. Measuring household resilience to food insecurity: Application to Palestinian households. Linking Information and Decision Making to Improve Food, EC-FAO Food Security Program.

Angelucci, M., Attanasio, O., Di Maro, V., 2012. The Impact of Oportunidades on Consumption, Savings and Transfers. Fiscal Studies 33, 305-334. http://dx.doi.org/ 10.1111/j.1475-5890.2012.00163.x.

American Institutes for Research, 2014. 12-Month Impact Report for Zimbabwe's Harmonised Social Cash Transfer Programs. Author, Washington, DC. 
Arnold, C., Conway, T., Greenslade, M., 2011. Cash Transfers Literature Review. Department for International Development (DfID).

Ballard, T.J., Kepple, A.W. \& Cafiero, C. (2013). The food insecurity experience scale: development of a global standard for monitoring hunger worldwide. Technical Paper. Rome, FAO. Retrieved from http://www.fao.org/economic/ess/ess-fs/voices/en/.

Bhalla, Garima; Handa, Sudhanshu; Angeles, Gustavo; Seidenfeld, David (2016). The Effect of Cash Transfers and Household Vulnerability on Food Insecurity in Zimbabwe, Innocenti Working Papers no. IWP_2016_22, UNICEF Office of Research Innocenti, Florence.

Behrman, J.R., Deolalikar, A.B., 1987. Will developing country nutrition improve with income? a case study for rural South India. J. Polit. Econom. 95, 108-138.

Chaudhuri, S., Jalan, J., \& Suryahadi, A. (2002). Assessing household vulnerability to poverty from cross-sectional data: A methodology and estimates from Indonesia. Retrieved from http://academiccommons.columbia.edu/catalog/ac:112942.

Coates, J., Frongillo, E.A., Rogers, B.L., Webb, P., Wilde, P.E., Houser, R., 2006. Commonalities in the experience of household food insecurity across cultures: what are measures missing? J. Nutrit. 136 (5), 1438S-1448S.

Coates, J., Swindale, A., \& Bilinsky, P. (2007). Household Food Insecurity Access Scale (HFIAS) for measurement of household food access: indicator guide (v. 3). Food and Nutrition Technical Assistance Project, Academy.

Dercon, S. (2001). Assessing vulnerability. Publication of the Jesus College and CSAE, Department of Economics, Oxford University. Retrieved from http://info.worldbank. org/etools/docs/library/70436/4th\%20Workshop/Srmafrica/helsinki/pdf/ readingmaterial/Assessing\%20Vulnerability.pdf.

FEWS NET ((2016, March). Drought conditions to significantly reduce 2015/16 harvests and affect livelihoods. Zimbabwe Food Security Outlook February 2016 to September 2016.Retrieved from http://www.fews.net/sites/default/files/documents/reports/ ZW_FSO_2016_02.pdf.

FEWS NET (2013, July). Reduced incomes and high food prices are expected to increase food insecurity among poor households in south-western districts. Zimbabwe Food Security Outlook July 2013 to March 2014. Retrieved from http://www.fews.net/ sites/default/files/documents/reports/Zimbabwe_FSO_07_2013.pdf.

FEWS NET (2014, March). Zimbabwe Food Security Brief. Retrieved from http://www. fews.net/sites/default/files/documents/reports/Zimbabwe Food Security Brief 2014_0.pdf.

FAO (2009). Declaration of the World Summit on Food Security, World Summit on Food Security, Rome, 16-18 November. Retrieved from ftp://ftp.fao.org/docrep/fao/ Meeting/018/k6050e.pdf.

FAO, IFAD and WFP (2014). The State of Food Insecurity in the World 2014. Strengthening the enabling environment for food security and nutrition. Rome, FAO.

FAO, IFAD and WFP. (2015). The State of Food Insecurity in the World 2015. Meeting the 2015 international hunger targets: taking stock of uneven progress. Rome, FAO.

Garcia, M., \& Moore, C. M. T. (2012). The Cash Dividend: The Rise of Cash Transfer
Programs in Sub-Saharan Africa. The World Bank. Retrieved from http://elibrary. worldbank.org/doi/book/10.1596/978-0-8213-8897-6.

Handa, S., Seidenfield, David, Prosper Matondi, \& Lazarus Zanamwe. (2013, March 1). Comprehensive Methodology Report for the Impact Evaluation of Zimbabwe's Harmonized Social Cash Transfer Program. American Institue of Research.

Hoddinott, John, \& Quisumbing, Agnes. (2003, December). Methods for Microeconometric Risk and Vulnerability Assessments. Social Protection Unit, Human Development Network The World Bank.

Jones, A.D., Ngure, F.M., Pelto, G., Young, S.L., 2013. What are we assessing when we measure food security? a compendium and review of current metrics. Adv. Nutrit. Internat. Rev. J. 4 (5), 481-505. http://dx.doi.org/10.3945/an.113.004119.

The Kenya CT-OVC Evaluation Team, 2012. The impact of the Kenya cash transfer program for orphans and vulnerable children on household spending. J. Develop. Effect. 4 (1), 9-37. http://dx.doi.org/10.1080/19439342.2011.653980.

Mango, N., Zamasiya, B., Makate, C., Nyikahadzoi, K., Siziba, S., 2014. Factors influencing household food security among smallholder farmers in the Mudzi district of Zimbabwe. Develop. Southern Africa 31 (4), 625-640. http://dx.doi.org/10.1080/ 0376835X.2014.911694.

Miller, C.M., Tsoka, M., Reichert, K., 2011. The impact of the social cash transfer scheme on food security in Malawi. Food Policy 36 (2), 230-238. http://dx.doi.org/10.1016/ j.foodpol.2010.11.020.

Nielsen, M. E., \& Olinto, P. (2007). Do conditional cash transfers crowd out private transfers? Evidence from randomized trials in Honduras and Nicaragua. Unpublished Manuscript, Princeton University, Princeton, NJ. Retrieved from http://www.cid. harvard.edu/neudc07/docs/neudc07_s1_p07_nielsen.pdf.

Nyikahadzoi, K., Zamasiya, B., Muchinako, G.A., Dziro, C., 2013. enhancing social support system for improving food security among the elderly headed household in communal areas of Zimbabwe. J. Food Res. 2 (3). http://dx.doi.org/10.5539/jfr. v2n $3 \mathrm{p} 46$.

Radimer, K.L., Olson, C.M., Campbell, C., 1990. Development of indicators to assess hunger. J. Nutrit. 120 (Suppl (11)), 1544-1548.

Strobbe, F., \& Miller, C. (2011). Cash Transfers in an Epidemic Context The Interaction of Formal and Informal Support in Rural Malawi. Policy Research Working Paper No. WPS 5824. Washington, DC. World Bank.

Subramanian, S., Deaton, A., 1996. The demand for food and calories. J. Polit. Econom. 104 (1), 133-162.

Swindale, A., Bilinsky, P., 2006. Household dietary diversity score (HDDS) for measurement of household food access: indicator guide. Food and Nutrition Technical Assistance Project, Academy for Educational Development, Washington, DC.

Webb, P., Coates, J., Frongillo, E.A., Rogers, B.L., Swindale, A., Bilinsky, P., 2006. Measuring household food insecurity: why it's so important and yet so difficult to do. J. Nutrit. 136 (5), 1404S-1408S. 